\title{
PROBLEMATYKA HALSZTACKICH \\ TZW. NAGOLENNIKÓW PUSTYCH WEWNĄTRZ \\ Z TERENU POLSKI NA PRZYKŁADZIE ZNALEZISKA GROMADNEGO Z OKOLIC TYKOCINA, POW. BIAŁOSTOCKI
}

\author{
AN ARTEFACT FROM A DEPOSIT DISCOVERED IN THE VICINITY \\ OF TYKOCIN, BIAŁYSTOK DISTRICT, AS AN EXAMPLE \\ OF THE SO-CALLED HOLLOW HALLSTATT ANKLETS \\ FROM THE POLISH TERRITORY
}

\begin{abstract}
Abstrakt: Artykuł dotyczy brązowych, niezdobionych tzw. nagolenników pustych wewnątrz. Problematyka tego typu zabytków została przedstawiona na przykładzie pochodzącego najprawdopodobniej ze skarbu znaleziska z okolic Tykocina. W skład depozytu wchodziła również „bransoleta” z zachodzącymi końcami, „aplikacje” oraz dwa drobne fragmenty innych przedmiotów, zapewne ozdób. Niezdobiony wariant tzw. nagolenników pustych wewnątrz jest reprezentowany zdecydowanie mniej licznie niż wariant zdobiony. Większość okazów z terenu Polski pochodzi z Pomorza; poza nim spotyka się pojedyncze egzemplarze. Nieliczne znaleziska wariantu niezdobionego z terenu Niemiec również występują w rozproszeniu. Omawiany typ wyrobów nie jest jednorodny. Chronologia większości znalezisk przypada na okres halsztacki C.
\end{abstract}

Słowa kluczowe: tzw. nagolenniki puste wewnątrz, epoka brązu, okres halsztacki C, skarb, Tykocin

Abstract: This article presents the so-called bronze undecorated hollow anklets. Features of this type of artefacts are elucidated in the following description of an item which most likely constitutes a part of a hoard discovered in the vicinity of Tykocin. This deposit also consisted of a "bracelet" with overlapping ends, "appliqués" and two small fragments of other objects, possibly jewellery. The undecorated variety of the so-called hollow anklets is represented in markedly lower numbers than the decorated type. Most specimens found in Poland come from Pomerania; outside this area only isolated ones have been discovered. Rather few objects representing the undecorated anklets in Germany were also dispersed. Artefacts of this type are not homogeneous and most are dated to the Hallstatt $\mathrm{C}$ period.

Keywords: so-called hollow anklets, Bronze Age, Hallstatt C period, hoard, Tykocin

${ }^{a}$ Dr Joanna Urban, Ośrodek Interdyscyplinarnych Badań Archeologicznych, Instytut Archeologii i Etnologii Polskiej Akademii Nauk, al. Solidarności 105, 00-140 Warszawa, jurban@tlen.pl, ORCID iD: https://orcid.org/0000-0003-0714-7753.

${ }^{b}$ Dr Małgorzata Mogielnicka-Urban, ul. Szekspira 2/409, 01-913 Warszawa, malmog@interia.pl, iD: https://orcid.org/0000-0003-3675-6582. 


\section{OKOLICZNOŚCI ZNALEZIENIA I SKŁAD ZNALEZISKA}

Zarówno kontekst, jak i miejsce znalezienia kilkunastu wyrobów brązowych, wśród których znajdował się tzw. nagolennik pusty wewnątrz wymieniony w tytule niniejszego artykułu, nie są dokładnie znane. Omawiane przedmioty, uznane roboczo za skarb ${ }^{1}$, zostały przekazane ówczesnemu właścicielowi zamku w Tykocinie inż. Jackowi Nazarko, który w 2009 r. udostępnił je mgr. Wojciechowi Bisowi (2015), prowadzącemu badania archeologiczne na zamku, celem opracowania i włączenia w naukowy obieg informacji ${ }^{2}$. Ofiarodawca nic nie wiedział o okolicznościach, w jakich natrafiono na depozyt, gdyż jak to często bywa w podobnych przypadkach, osoba, od której pozyskał znaleziska, wolała pozostać anonimowa i zasłaniała się niewiedzą na ten temat. Wiadomo tylko, iż pochodziły one z okolic Tykocina.

Do opracowania trafił zespół (ryc. 1) złożony z dwóch ozdób obręczowych: jednej pustej wewnątrz, określanej dalej mianem „nagolennika”, drugiej z zachodzącymi końcami, wykonanej z pełnego pręta, opisywanej jako „bransoleta”, oraz niewielkich miseczkowatych ozdób, zwanych następnie „aplikacjami”, i dwóch drobnych fragmentów trudnych do określenia przedmiotów brązowych (tabela 1).

Omawiane wyroby zapewne znaleziono razem. Świadczy o tym podobny rodzaj gleby, jaką były zanieczyszczone. Jej próbkę, pobraną z wnętrza większej z ozdób oraz znajdującej się razem z ww. zabytkami, poddano analizie chemicznej ${ }^{3}$. Wykazała ona, iż ziemia ta pochodzi ze środowiska przesyconego wodą, kwaśnego, o niskim potencjale utleniającym, a zatem najprawdopodobniej ze środowiska bagiennego. Może to przemawiać za tym, że pierwotnie przedmioty zdeponowano $\mathrm{w}$ środowisku wodnym lub podmokłym. Tego typu tereny charakteryzują okolice Tykocina także w chwili obecnej.

Wątpliwości, co do tego czy mamy do czynienia ze zwartym zespołem, budzi fakt stwierdzenia w omawianym zbiorze patyny o różnym zabarwieniu (tabela 1). Dotyczy to zwłaszcza „aplikacji” pokrytych ciemnozielonym nalotem. Przynależność tych przedmiotów do opisywanego depozytu jest niepewna także z powodu pewnej ich odmienności stylistycznej. Niejasne okoliczności pozyskania znaleziska budzą wątpliwości, czy możemy mówić o jego pełnym składzie.

„Bransoleta” (ryc.2) - wchodząca poza „nagolennikiem” w skład „skarbu” - należy do wytworów ludności kultury łużyckiej, charakterystycznych zwłaszcza dla grupy górnośląsko-małopolskiej (Dobrzańska-Szydłowska, Gedl 1962, s. 93),

${ }^{1}$ Kwestie terminologiczne nie są przedmiotem niniejszego artykułu, jednak warto nadmienić, iż w literaturze archeologicznej pojęcie to jest różnie definiowane (por. np. Brunn v. 1968, s. 236; Willroth 1984, s. 48; Bukowski 1998, s. 27). Na ogół jednak za „skarb” uważa się znalezisko składające się $\mathrm{z}$ więcej niż jednego przedmiotu, deponowane w jednym miejscu, celowo, jednoczasowo lub w ciągu dłuższego okresu czasu (por. np. Stjernquist [1962-1963] 1963, s. 19-22; Kubach 1985, s. 179). Ze względu na to, iż w tej nazwie zawarta jest już konotacja znaczeniowa, wskazująca na potencjalną wartość materialną, której obecnie nie można odtworzyć, właściwszym wydaje się bardziej neutralny termin, jak „znalezisko gromadne”. Jednak ze względów praktycznych oba będą stosowane zamiennie.

${ }^{2}$ Warunkiem wypożyczenia była obietnica szybkiego zwrócenia zabytków znalazcy, co też uczyniono.

${ }^{3}$ Analizę przeprowadził dr Rafał Siuda z Instytutu Geologii Uniwersytetu Warszawskiego. 


\section{DISCOVERY AND CONTENTS OF THE ASSEMBLAGE}

Neither the context, nor the place of discovery of the assemblage of more than ten bronze objects, including the so-called hollow anklet in question, is precisely known. These objects, with a preliminary classification of a hoard ${ }^{1}$, were given over to the owner of the Tykocin castle at that time, Jacek Nazarko. His intention of documenting the artefacts and diffusion of information prompted him to grant access to the assemblage to Wojciech Bis, MA (2015), who conducted archaeological research at the castle ${ }^{2}$. The contributor did not possess any information concerning the circumstances in which the deposit had been discovered as the person who delivered the artefacts preferred to remain anonymous and denied any knowledge of relevant details. It was only established that the material came from the vicinity of Tykocin.

The assemblage (Fig. 1) accessible for identification consisted of two ring jewellery pieces: one was hollow and later referred to as an "shin ring", another one with overlapping ends, made of a solid rod, described as an "anklet, as well as small cup-shaped ornaments, further on called "appliqués" and two small fragments of bronze objects, which are difficult to identify (Table 1).

The items in question were probably found deposited together. It is suggested by the soil with which they were covered. Samples of the soil recovered from the inner part of the larger ornament as well as the soil found with the artefacts were subjected a chemical analysis ${ }^{3}$. The results indicated that the soil came from a waterlogged environment characterized by acidity and low oxidative potential, most likely a bog. It might suggest that the objects were initially deposited in water or wet area. Environment of this type can still be found in the proximity of Tykocin.

The fact that patina of various colours (Table 1) was found in the assemblage raises doubts whether the artefacts come from a sealed context. It is particularly relevant in the case of the "appliqués" covered with dark green patina. The association of these items with the deposit is also uncertain due to their stylistic diversity from the other objects. The unclear circumstances of the discovery raise questions about the completeness of the assemblage.

The "bracelet" (Fig. 2), which constitutes the hoard together with the "anklet", is an artefact associated with the industry of the Lusatian culture, particularly characteristic for the Upper Silesian-Lesser Poland group (Dobrzańska-Szydłowska, Gedl 1962, p. 93), although they can be found outside its territory. The chronology

1 Terminology issues are not a subject of this article, however, it should be mentioned that archaeological literature presents several different definitions of this term (cf. e.g. Brunn v. 1968, p. 236; Willroth 1984, p. 48; Bukowski 1998, p. 27). Usually, a "hoard" is a find consisting of more than one item, deposited in one spatial context, intentionally, either on one occasion or over a longer period (cf. e.g. Stjernquist [1962-1963] 1963, pp. 19-22; Kubach 1985, p. 179). Due to the fact that this term represents a meaning associated with a potential high material value, which cannot be reconstructed at present, it seems that a more neutral denomination, such as a "multiple find", is more relevant. For practical reasons, both terms will be used as equivalent.

2 The owner agreed to lend the objects on condition of prompt return of the assemblage.

${ }^{3}$ The analysis was conducted by Dr Rafał Siuda from the Institute of Geology of the University of Warsaw. 


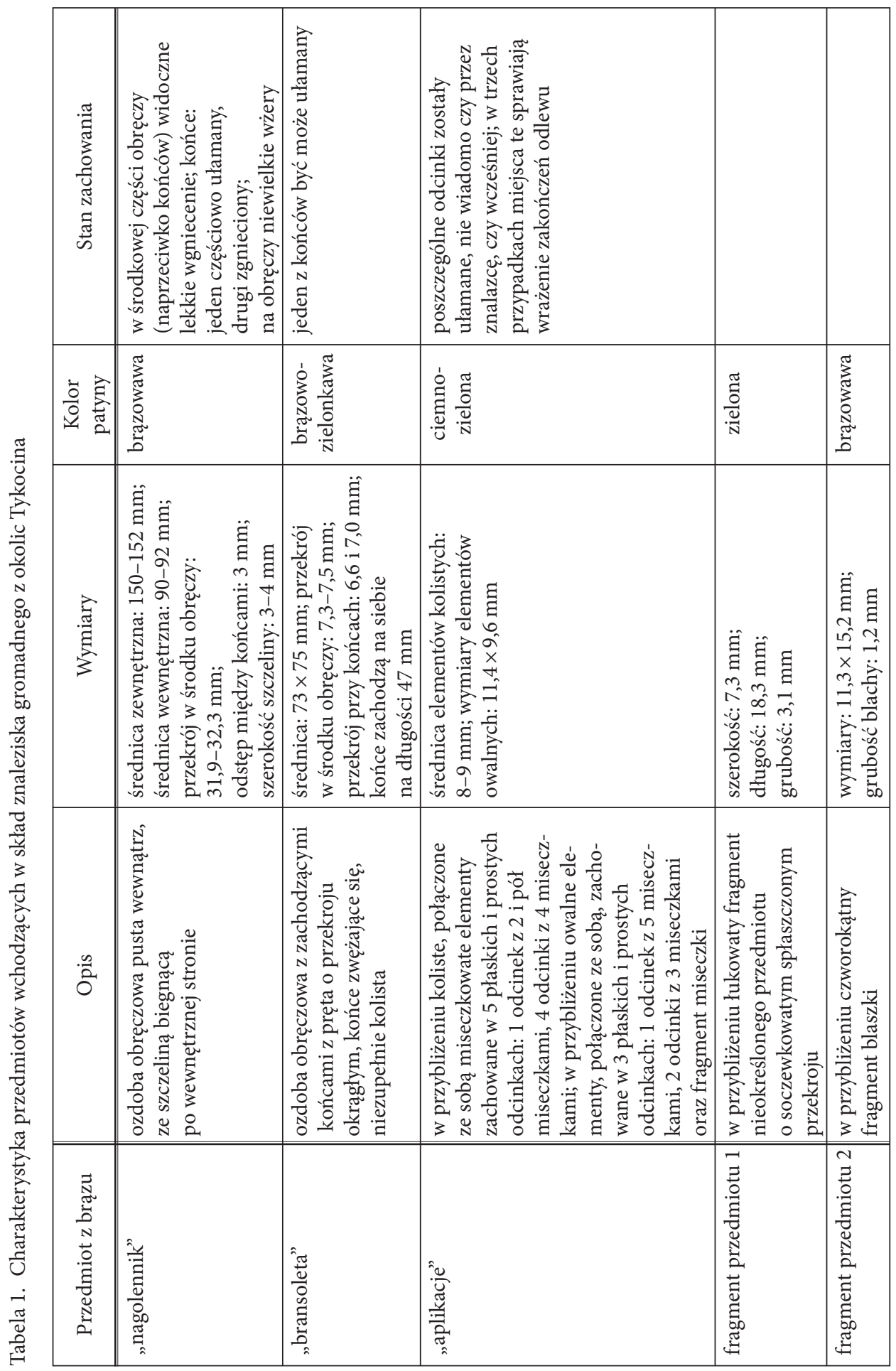




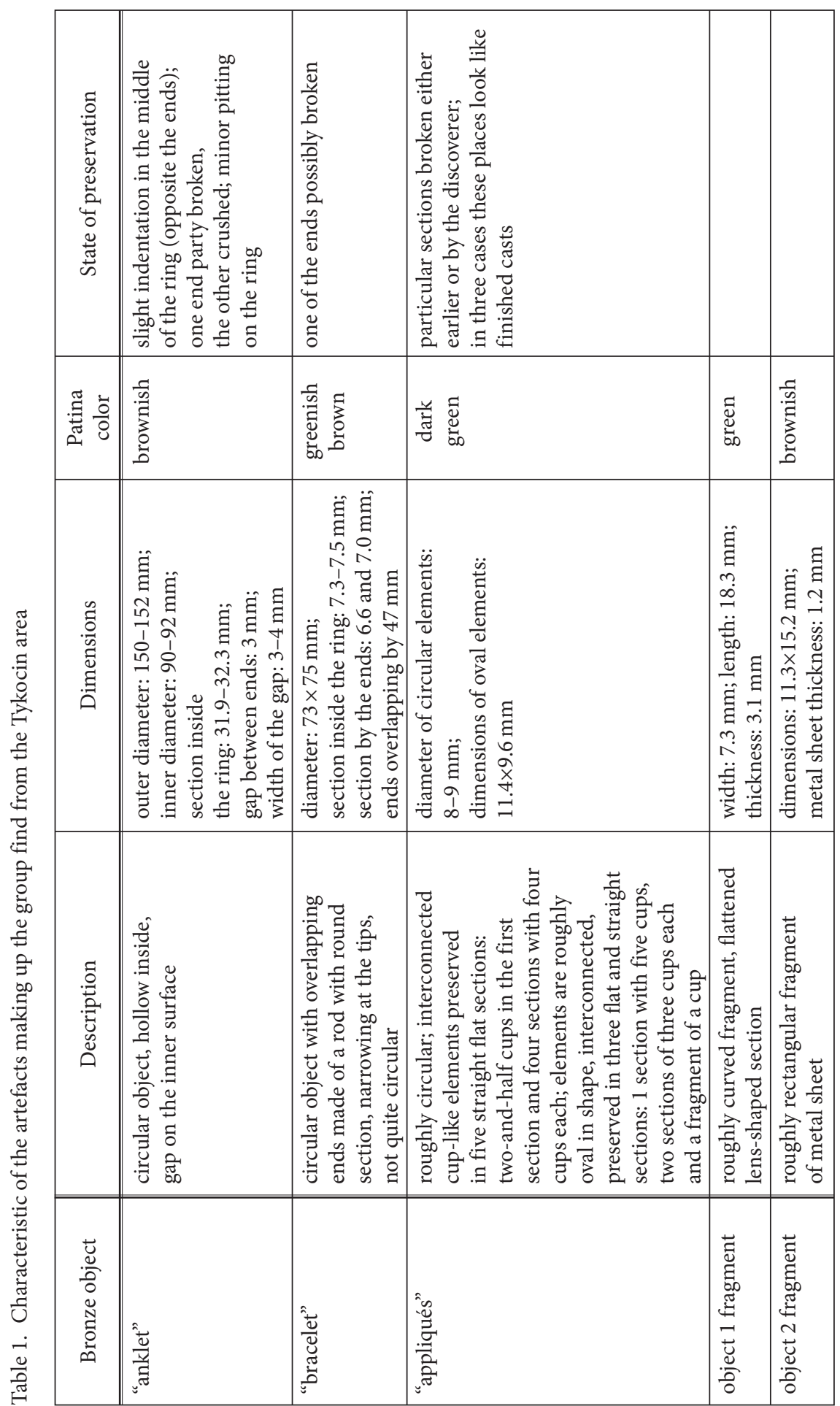



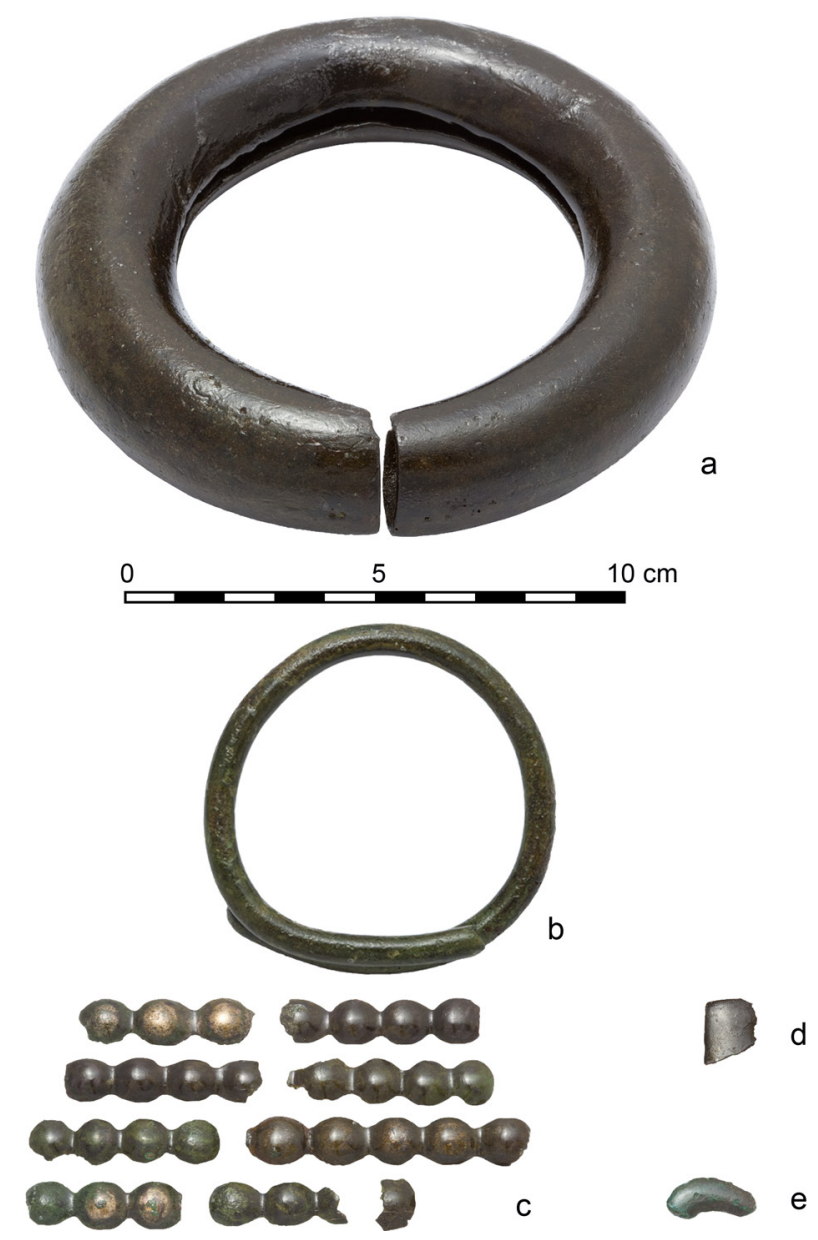

Ryc. 1. Zawartość znaleziska gromadnego z okolic Tykocina, pow. białostocki a - „nagolennik”; b - „bransoleta”; c - aplikacje; d - łukowaty fragment przedmiotu brązowego; e - prostokątny fragment przedmiotu brązowego.

Fot. M. Osiadacz

Fig. 1. Contents of the multiple find from the vicinity of Tykocin, Białystok district a - "anklet"; b - "bracelet"; c - appliqués; d - bow-shaped fragment of the bronze artefact; e - rectangular fragment of the bronze artefact.

Photo M. Osiadacz

choć występujących także poza jej terytorium. Datowanie tego typu ozdób mieści się pomiędzy V okresem epoki brązu (dalej: EB) a okresem halsztackim C (dalej: HC). Usytuowanie niektórych egzemplarzy w grobach szkieletowych (np. Błaszczyk 1965, s. 174) oraz ich zróżnicowanie wielkościowe wskazują, iż mogły pełnić funkcję zarówno ozdób rąk, jak i nóg. Interesujące jest, że pojedynczy okaz takiej „bransolety" wystąpił w podobnym kontekście jak w Tykocinie, w skarbie ze Słupów, pow. aleksandrowski (Durczewski [1960] 1961, s. 89, ryc. 51: 10). 


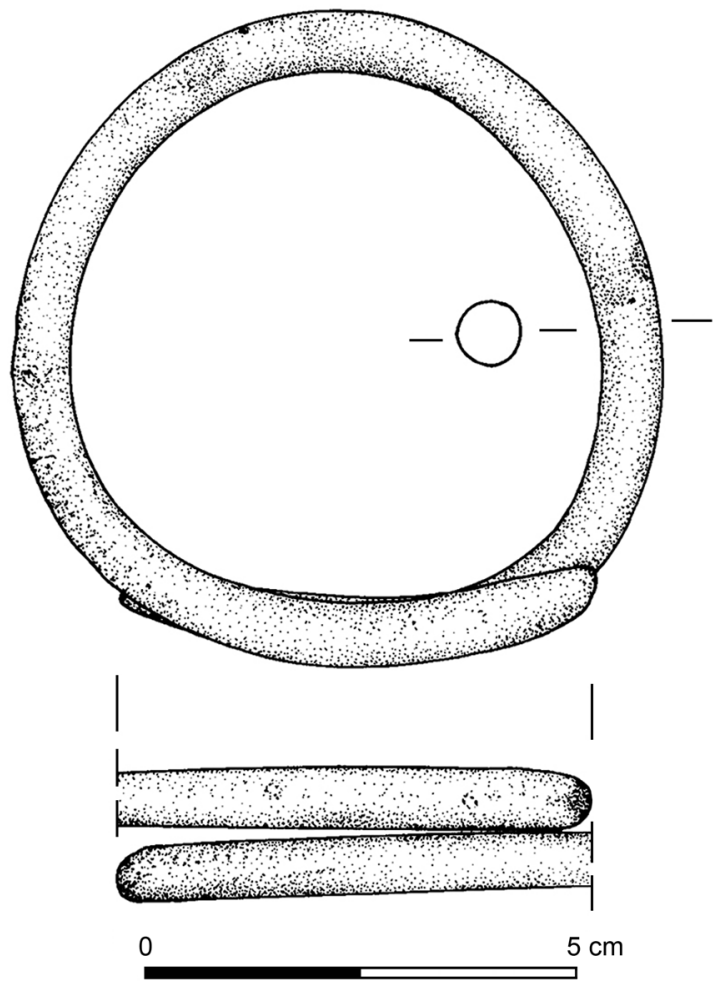

Ryc. 2. „Bransoleta” ze „skarbu” z okolic Tykocina.

Rys. G. Nowakowska

Fig. 2. "Bracelet" from the "hoard" from the vicinity of Tykocin.

Drawing G. Nowakowska

of this type of jewellery ranges from the Bronze Age period V (BA) to the Hallstatt C period (HC). Presence of some specimens in skeletal burials (e.g. Błaszczyk 1965 , p. 174) and the variety of their sizes indicate that they might have been used as both arm and leg jewellery. Interestingly, an isolated specimen of such a "bracelet" was found in the hoard of Słupy, Aleksandrów Kujawski district, in a context which was similar to the one associated with Tykocin (Durczewski [1960] 1961, p. 89, Fig. 51: 10).

The cup-shaped ornaments (Fig. 3), which are another element of the assemblage, do not have accurate parallels among Bronze Age and Early Iron Age artefacts in the area of the so-called Lusatian culture. Nevertheless, examples of a different type of bronze ornaments have been observed at sites associated with this culture, especially in the Upper Silesian-Lesser Poland group. An eight-shaped plano-convex bronze knob, measuring $2.8 \mathrm{~cm}$ in length and $1.1 \times 0.8 \mathrm{~cm}$ in the diameter of the cups, found in a tomb 1395 in Opatów, Kłobuck district (Szczepanek et al. 2007, p. 645 , Fig. 5 g), might be treated as similar to a certain extent. It could be supposed that the specimens from Tykocin served for the decoration of stiff and flat surfaces 
Miseczkowate ozdoby (ryc. 3), stanowiące kolejny element opisywanego zespołu, nie znajdują ścisłych analogii wśród wyrobów z epoki brązu i wczesnej epoki żelaza z terenu tzw. kultury łużyckiej, choć przykłady innego rodzaju aplikacji brązowych są obserwowane na stanowiskach tej kultury, zwłaszcza w grupie górnośląsko-małopolskiej. Do pewnego stopnia jako podobny można traktować podwójny płasko-wypukły guz brązowy ósemkowatego kształtu o długości 2,8 cm, średnicy miseczek $1,1 \times 0,8 \mathrm{~cm}$, znaleziony w grobie $1395 \mathrm{z}$ Opatowa, pow. kłobucki (Szczepanek i in. 2007, s. 645, ryc. 5g). Przypuszczać można, iż okazy z Tykocina mogły służyć do ozdobienia powierzchni płaskich, sztywnych, a miejscem przymocowania do podłoża było przewężenie pomiędzy miseczkowatymi elementami. Mniej prawdopodobne wydaje się ich zastosowanie przy zdobieniu miękkiej odzieży lub opasek.

Drobny fragment o kształcie prostokątnym (ryc. 4a), mógł służyć jako rodzaj „okładziny”. Przemawia za tym fakt, iż jego spodnia strona jest chropowata, nieobrobiona po odlaniu. Odtworzenie jego pierwotnego kształtu na podstawie zachowanego ułamka jest niemożliwe.

Drugi fragment (ryc. 4b) może stanowić część kolistej ozdoby (?), a nie aplikacji czy okładziny, na co wskazuje jego soczewkowaty, spłaszczony przekrój. Być może mamy do czynienia z jakiegoś rodzaju zawieszką, która mogła być wykorzystywana np. przy uprzęży końskiej.

Niezależnie od swego pierwotnego przeznaczenia, zarówno „aplikacje”, jak i fragmenty dwóch kolejnych przedmiotów mogły stanowić złom brązowy lub półprodukt („aplikacje”) do dalszej obróbki.

\section{OPIS „NAGOLENNIKA”}

Typ zabytków będący przedmiotem niniejszego artykułu zaliczany jest do kategorii ozdób ciała. Kwestia stosowanego dla niego nazewnictwa wymaga kilku słów komentarza. Zwyczajowo tak wyglądające wyroby określano w literaturze przedmiotu mianem nagolenników (Kostrzewski 1958, s. 194) bądź naramienników (Szafrański 1955, s. 63), a niekiedy także bransolet, a nawet naszyjników (np. Łuka 1966, s. 165). Zróżnicowanie to, sugerujące rozmieszczenie ozdób na ciele, uzasadniały jedynie wymiary poszczególnych okazów lub wyobraźnia badacza. Niejasne kryteria skutkowały nie tylko tym, że te same znaleziska były różnie nazywane przez poszczególnych autorów, ale także tym, iż niekiedy w pracach jednego badacza można było znaleźć ten sam przedmiot różnie określany ${ }^{4}$. Niektórzy autorzy słusznie zauważają, że zróżnicowanie wielkościowe poszczególnych okazów wskazuje, iż mogły być one noszone na różnych częściach ciała, wobec czego tak szczegółowy podział jest bezcelowy (Dąbrowski 1997, s. 63), zaś określenie rzeczywistego przeznaczenia tych ozdób jest praktycznie nie do odtworzenia, jeżeli nie dysponujemy ich lokalizacją w grobie w stosunku do szkieletu (np. Błaszczyk 1965, s. 174).

${ }^{4}$ Na przykład ozdobę z Dankowa, pow. koniński, Józef Kostrzewski raz określa mianem naramiennika (Kostrzewski 1923, s. 262 przypis 314), a raz nagolennika (Kostrzewski [1962] 1964, s. 29, ryc. 13). 

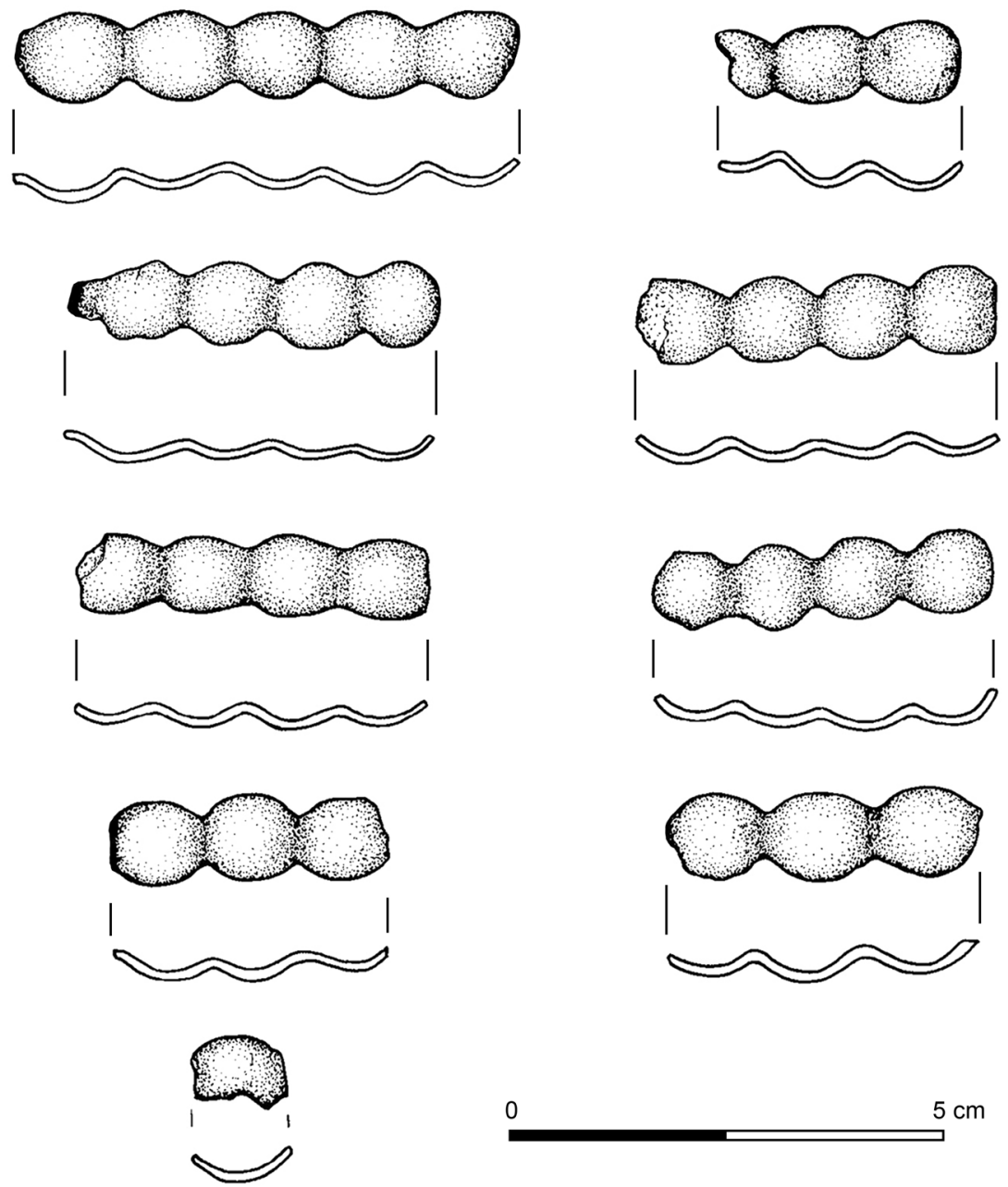

$5 \mathrm{~cm}$

Ryc. 3. „Aplikacje” ze „skarbu” z okolic Tykocina.

Rys. G. Nowakowska

Fig. 3. "Appliqués" from the "hoard" from the vicinity of Tykocin.

Drawing G. Nowakowska

and that the narrow place between the cup-shaped elements was used as a fastening site. Their application for embellishment of soft clothing or rings seems less likely.

A small rectangular fragment (Fig. 4a) might have served as a type of "lining". It is suggested by the fact that its underside is rough, unpolished after casting. It is impossible to reconstruct its original shape on the basis of the preserved fragment.

Another fragment (Fig. 4b) could be a part of a circular ornament or jewellery piece (?), but not an appliqué or lining, which is indicated by its lens-shaped flattened section. Perhaps it is a type of a pendant which might have been used e.g. in a horse bridle. 

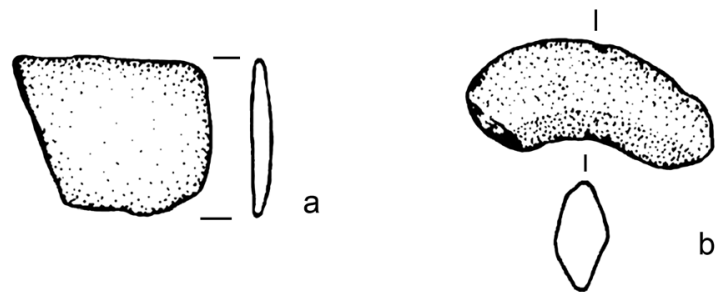

0 $5 \mathrm{~cm}$

Ryc. 4. Fragmenty przedmiotów brązowych ze „skarbu” z okolic Tykocina a - fragment „prostokątny”; b - fragment „łukowaty”.

Rys. G. Nowakowska

Fig. 4. Fragments of bronze artefacts from the "hoard" from the vicinity of Tykocin a - "rectangular" fragment; b - "bow-shaped" fragment.

Drawing G. Nowakowska

W związku z powyższym pojawiły się propozycje bardziej neutralnego nazewnictwa, niezawierającego konotacji funkcjonalnej, jak np. obręczowe ozdoby rąk i nóg (Blajer 2001, s. 166). Słuszne pod względem formalnym, są jednak niepraktyczne w stosowaniu ze względu na swój opisowy charakter, wymagający w konkretnych przypadkach dodatkowego uszczegółowienia. Dlatego też w niniejszej pracy postanowiono posługiwać się tradycyjnym określeniem typu omawianych przedmiotów, sygnalizując jednocześnie umowność tej nazwy poprzez poprzedzenie jej wyrażeniem „tak zwany” bądź podając ją w cudzysłowie. Podobnie, w przypadku drugiej ozdoby obręczowej z Tykocina użyto terminu „bransoleta”, zdając sobie sprawę, iż nie przesądza on o funkcji tego okazu.

Opisywany tzw. nagolennik ma kształt kolistej obręczy w przybliżeniu o okrągłym przekroju, pustej wewnątrz, z podłużną szczeliną biegnącą wzdłuż całej długości po wewnętrznej stronie obręczy (ryc. 5). Jej końce nie stykają się ze sobą, pozostaje zachowany między nimi odstęp szerokości około $0,3 \mathrm{~cm}$. Średnica zewnętrzna zabytku wynosi około $15 \mathrm{~cm}$, a wewnętrzna około $9 \mathrm{~cm}$ (tabela 1). Jego stan zachowania - podobnie jak i innych elementów depozytu - jest stosunkowo dobry, mimo iż w środkowej części obręczy (naprzeciwko końców) daje się zauważyć lekkie wgniecenie, a jeden z końców jest częściowo ułamany, drugi zaś zgnieciony. Dodatkowo na obręczy można zaobserwować niewielkie wżery, nie stwierdzono natomiast śladów kucia ani pozostałości po odlewie lub śladów ich zamaskowania. Brak jest więc bezpośrednich przesłanek dotyczących sposobu wykonania tego przedmiotu.

Analiza składu chemicznego wykazała, iż stop, z jakiego wykonano „nagolennik”, stanowi w blisko $93 \%$ miedź, a tylko w nieco ponad $1 \%$ cyna. Pozostałe pierwiastki stopowe to (w kolejności malejącej): antymon, ołów, arsen, nikiel, srebro, żelazo, cynk, aluminium, chrom, krzem, tytan i mangan; tylko antymon, ołów i arsen przekraczają $1 \%$ (tabela 2 ). Tak niskie, a przy tym wyrównane udziały tych pierwiastków nie pozwalają ocenić jednoznacznie, czy mamy tu do czynienia z brązem, czy raczej $\mathrm{z}$ miedzią stopową. 
Regardless of the original application, both the "appliqués" and the fragments of the two objects might have been bronze scrap material or half-products ("appliqués") for further processing.

\section{DESCRIPTION OF THE “ANKLET”}

The type of artefacts described in this article belongs to the category of body jewellery. The nomenclature requires a brief commentary. Literature refers to such objects as anklets (Kostrzewski 1958, p. 194) or arm rings (Szafrański 1955, p. 63), or sometimes bracelets and even neck rings (e.g. Łuka 1966, p. 165). This variety regarding distribution of the jewellery on the body was justified solely by the dimensions of different items and the scholar's imagination. Such unclear criteria resulted not only in various names for similar objects used by different authors but also in certain items being called with different names in different papers written by the same author ${ }^{4}$. Some scholars are right to note that the variety of sizes of different items indicates that they might have been worn on different parts of the body, and thus such a detailed division seems pointless (Dąbrowski 1997, p. 63). Moreover, it is practically impossible to establish the actual application of these jewellery pieces unless we are aware of their location in association with skeletal remains in burials (e.g. Błaszczyk 1965, p. 174).

As a consequence, a more neutral nomenclature was proposed, devoid of functional connotations, for instance ring jewellery for arms and legs (Blajer 2001, p. 166). While they are formally correct, these names are impractical due to their descriptive form and require more details in certain descriptions. For this reason, traditional names for these artefacts will be used throughout this work, with the arbitrary nature of the name emphasized by the use of "the so-called" preceding the name or by the use of quotation marks. In accordance with the same guidelines, the other piece of ring jewellery from Tykocin is referred to as a "bracelet", with a complete understanding that it does not define the function of the specimen.

The so-called anklet in question is a circular ring with a roughly round crosssection. It is hollow and has a gap running lengthwise in the inner part of the circlet (Fig. 5). Its ends do not meet or overlap, the gap between them is approx. $0.3 \mathrm{~cm}$ wide. The outer diameter of the specimen is approx. $15 \mathrm{~cm}$ and the inner one approx. $9 \mathrm{~cm}$ (Table 1). Its state of preservation - like in the case of other elements of the deposit - is relatively good, although a small indentation can be seen in the mid-portion of the ring (opposite the ends) and one end is partially broken, the other crushed. In addition to that, minor pitting marks can be seen on the ring surface, but no forging marks, casting marks or traces of masking thereof have been detected. Thus there are no direct indications concerning the manner of production of this object.

${ }^{4}$ For instance, Józef Kostrzewski referred to an ornament from Danków, Konin district, as an arm ring in one work (Kostrzewski 1923, p. 262 note 314), and as an anklet in another (Kostrzewski [1962] 1964, p. 29, Fig. 13). 


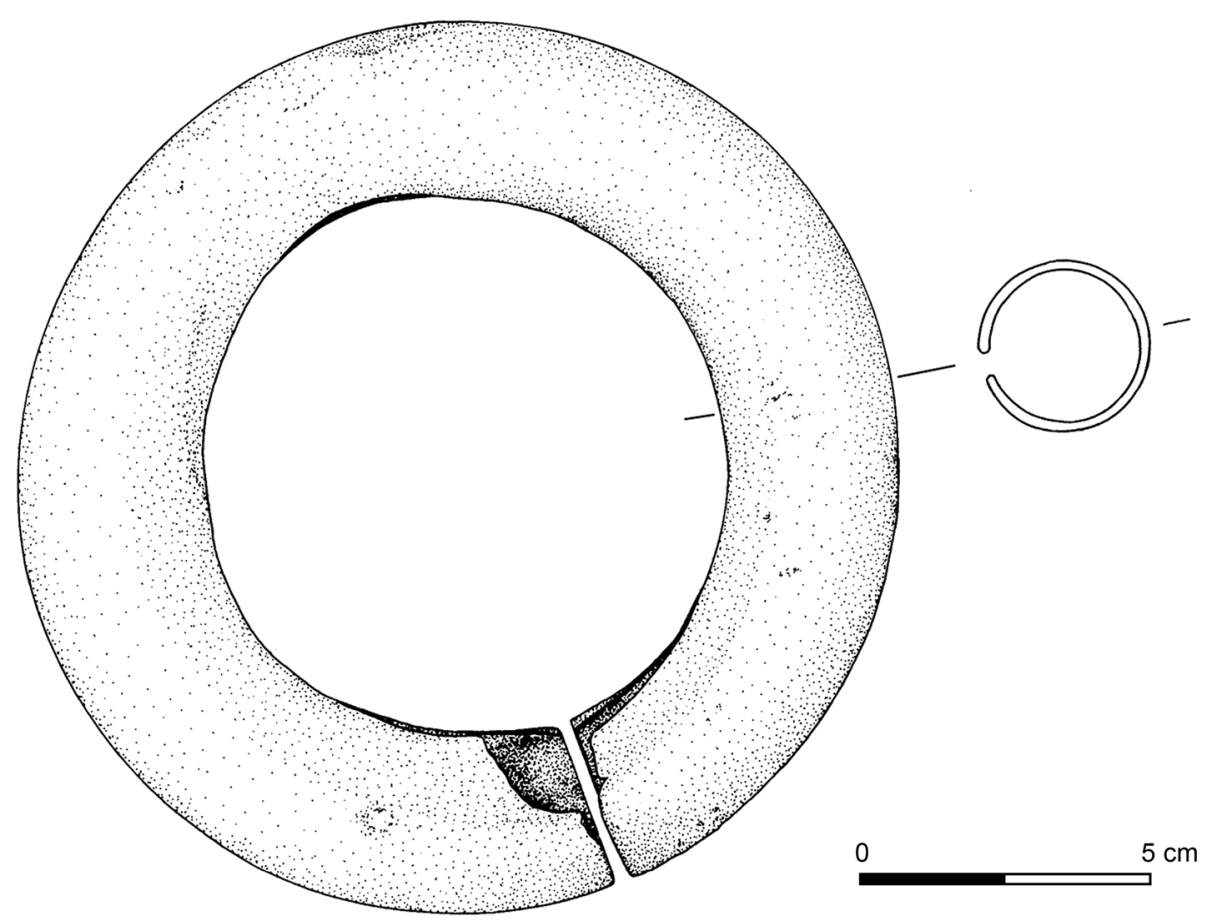

Ryc. 5. „Nagolennik” ze „skarbu” z okolic Tykocina.

Rys. G. Nowakowska

Fig. 5. "Shin ring" from the "hoard" from the vicinity of Tykocin.

Drawing G. Nowakowska

\section{TYPOLOGIA I ANALOGIE}

Biorąc pod uwagę formę i stylistykę wyrobu, zabytek z okolic Tykocina można zaliczyć do niezdobionego wariantu tzw. nagolenników pustych wewnątrz vel w środku ${ }^{5}$. Ten typ ozdób, określanych w literaturze niemieckiej mianem „Hohlwulste” (Schacht 1982, s.9-11) lub „Hohlwulstringe” (np. Kunkel 1931, s. 129; Simon 1972, s. 100), występuje licznie zarówno na terenie Niemiec, zwłaszcza północnych, jak i w północno-zachodniej Polsce ${ }^{6}$, a jego cechą charakterystyczną jest sposób wykonania.

W przeciwieństwie do znacznie bardziej rozpowszechnionego wariantu zdobionego (Schacht 1982, mapa) egzemplarze bez ornamentu występują zdecydowanie rzadziej (ryc. 6). Charakterystyczne przede wszystkim dla Pomorza, obecne są także

${ }^{5} \mathrm{~W}$ polskiej literaturze omawiany typ ozdób bywa także określany jako tzw. nagolenniki/naramienniki dęte (Chmielecki 1909, s. 163; Kostrzewski [1953] 1954, s. 25, tabela 1; Blajer 2001, s. 62).

${ }^{6}$ Pojedyncze egzemplarze zdobione lokalizowane są także na wschód od Wisły (Schacht 1982, mapa). 
Analysis of the chemical composition indicated that the alloy which the "anklet" was made of consists of nearly $93 \%$ of copper and slightly more than $1 \%$ of tin. The remaining elements of the alloy (from the highest to the lowest share) are as follows: antimony, lead, arsenic, nickel, silver, iron, zinc, aluminium, chromium, silicon, titanium and manganese; only antimony, lead and arsenic exceed 1\% (Table 2). It is impossible to establish whether it is bronze or rather alloy copper due to such a low and comparable content of these elements.

\section{TYPOLOGY AND PARALLELS}

Considering the form and style of the artefact, the object from the vicinity of Tykocin could be categorized as an unornamented variety of the so-called hollow anklets 5 . This type of jewellery, called "Hohlwulste" (Schacht 1982, pp.9-11) or "Hohlwulstringe" (e.g. Kunkel 1931, p. 129; Simon 1972, p. 100) in German literature, has been found in high numbers in Germany, particularly in the northern part, and in north-western Poland ${ }^{6}$. The manner of production is a characteristic feature of these artefacts.

The undecorated specimens are much less common (Fig. 6) as opposed to the more frequently represented decorated variety (Schacht 1982, Map). The former are characteristic mainly for Pomerania and have also been found in adjacent regions (Lubusz Land, Greater Poland, Kuyavia). The southernmost discoveries of this kind were made in Greater Poland and the easternmost in Podlachia. Isolated specimens come from Germany ${ }^{7}$ (cf. below).

It should be noted that some descriptions of such specimens in archaeological literature are very brief, e.g. "anklets" from Czersk, Chojnice district (Łuka 1966, pp. 84-85), Czarnowice, Krosno Odrzańskie district (Schacht 1982, p. 103, cat. no. 112) or Kołobrzeg (Kostrzewski [1951-1952] 1953, p. 201). Cases of assumption $a$ priori that a particular specimen belongs to the decorated variety are also relatively frequent (cf. e.g. Skrzypek [1995] 1996, Fig. 1.2), although the source literature does not provide relevant detailed information. Such is the case of the classification of jewellery from Mosina, Szczecinek district (Schacht 1982, p. 85) and Tczew (Sprockhoff 1956, p. 19). Some of the artefacts are in a rather poor state of preservation, e.g. they have broken or lost ends and this precludes conclusive association with the right variety. The latter happened e.g. in the case of artefacts from Mieroszyno and Mosina (see below), as well as Nowogard, Goleniów district (Kunkel 1932, p. 61).

${ }^{5}$ Polish literature also refers to such type of artefacts as the so-called "air-filled shin rings/arm rings" (Chmielecki 1909, p. 163; Kostrzewski [1953] 1954, p. 25, Table 1; Blajer 2001, p. 62).

${ }^{6}$ Isolated decorated specimens have also been found to the east of the Vistula River (Schacht 1982, Map).

7 This variety might have also been present in Denmark, however, the state of preservation of such specimens is too poor to conclusively identify them as belonging to this category (cf. Schacht 1982, pp. 68-69). 


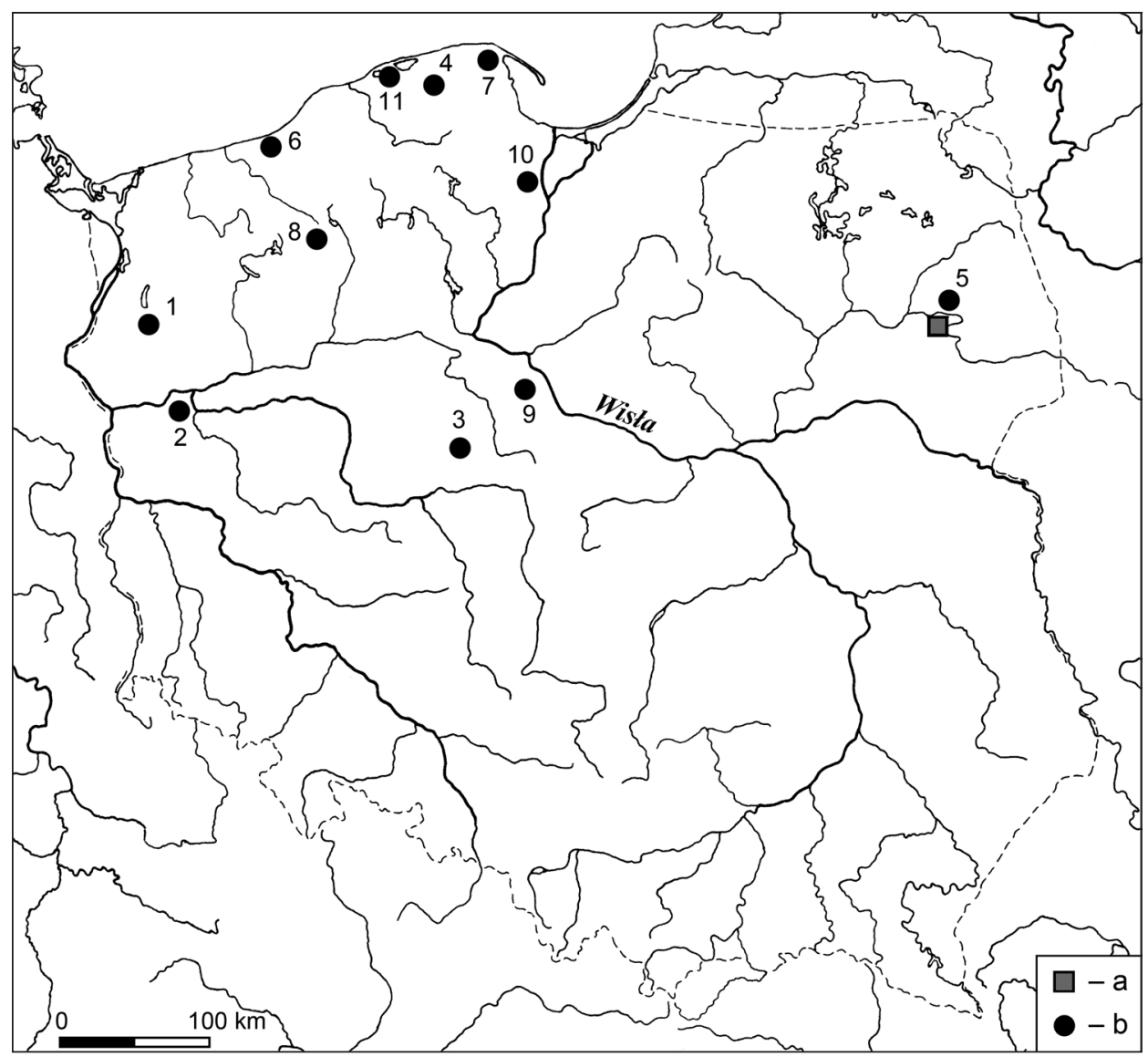

Ryc. 6. Rozmieszczenie znalezisk wariantu niezdobionego tzw. nagolenników pustych wewnątrz na terenie Polski

a - Tykocin, pow. białostocki, woj. podlaskie; b - pozostałe stanowiska: 1. Brzesko, gm. Pyrzyce, pow. pyrzycki, woj. zachodniopomorskie; 2. Ciecierzyce, gm. Deszczno, pow. gorzowski, woj. zachodniopomorskie; 3. Danków, gm. Kleczew, pow. koniński, woj. wielkopolskie; 4. Janowice, gm. Nowa Wieś Lęborska, woj. pomorskie; 5. Kalinówka Kościelna, gm. Knyszyn, pow. moniecki, woj. podlaskie; 6. Kazimierz Pomorski, gm. Będzino, pow. koszaliński, woj. zachodniopomorskie; 7. Mieroszyno, gm. Puck, pow. pucki, woj. pomorskie; 8. Mosina, gm. Szczecinek, pow. szczecinecki, woj. zachodniopomorskie; 9. Słupy, gm. Bądkowo, pow. aleksandrowski, woj. kujawsko-pomorskie; 10. Tczew, pow. tczewski, woj. pomorskie; 11. Żelazo, gm. Smołdzino, pow. słupski, woj. pomorskie.

Opracowały: merytorycznie - J. Urban, graficznie - A. Sołodko

Fig. 6. Distribution of sites with the undecorated variety of the so-called hollow anklets in Poland a - Tykocin, Białystok district, Podlachian Voivodeship; b - other sites: 1. Brzesko, Pyrzyce municipality, Pyrzyce district, West-Pomeranian Voivodeship; 2. Ciecierzyce, Deszczno municipality, Gorzów Wielkopolski district, West-Pomeranian Voivodeship; 3. Danków, Kleczew municipality, Konin district, Greater Poland Voivodeship; 4. Janowice, Nowa Wieś Lęborska municipality, Pomeranian Voivodeship; 5. Kalinówka Kościelna, Knyszyn municipality, Mońki district, Podlachian Voivodeship; 6. Kazimierz Pomorski, Będzino municipality, Koszalin district, West-Pomeranian Voivodeship; 7. Mieroszyno, Puck municipality, Puck district, Pomeranian Voivodeship; 8. Mosina, Szczecinek municipality, Szczecinek district, West-Pomeranian Voivodeship; 9. Słupy, Bądkowo municipality, Aleksandrów Kujawski district, Kuyavian-Pomeranian Voivodeship; 10. Tczew, Tczew district, Pomeranian Voivodeship; 11. Żelazo, Smołdzino municipality, Słupsk district, Pomeranian Voivodeship. 


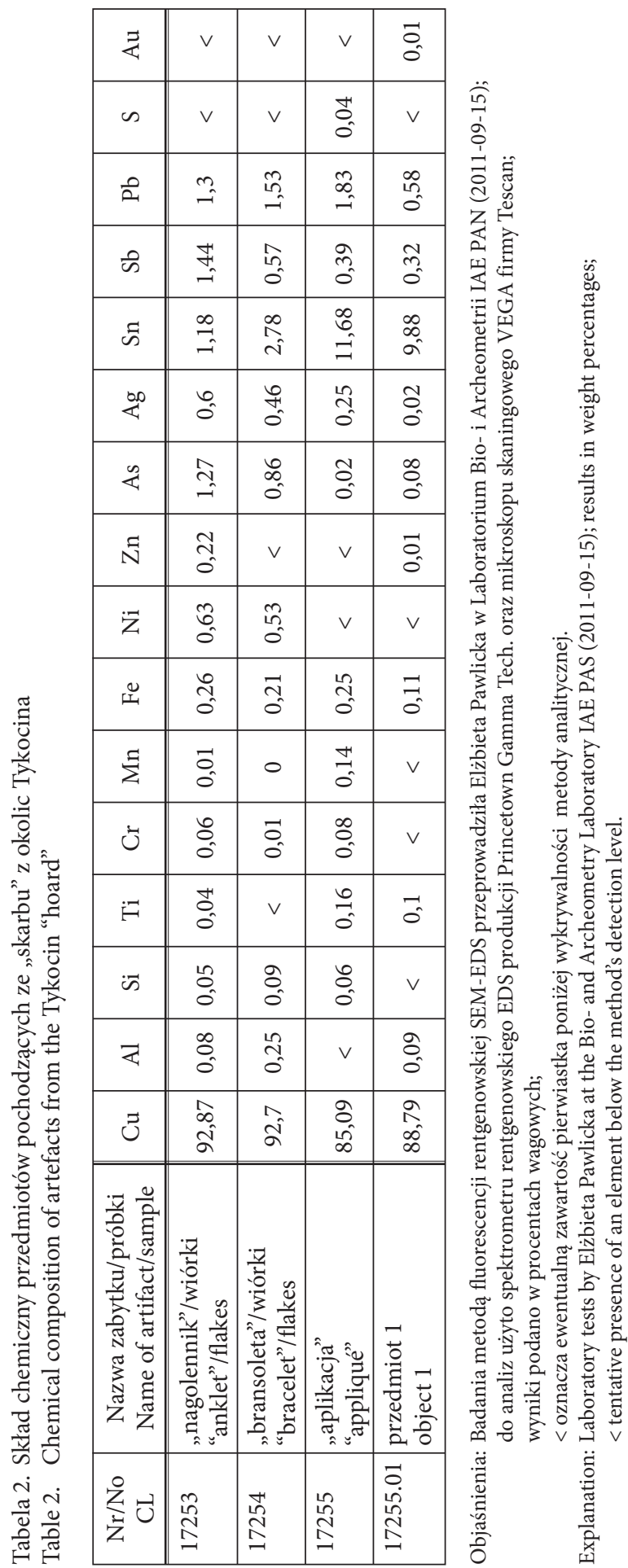


na terenach doń przyległych (Ziemia Lubuska, Wielkopolska, Kujawy). Najbardziej wysunięte na południe znaleziska tego typu odkryto w Wielkopolsce, natomiast najdalej na wschód - na Podlasiu. Pojedyncze okazy tego wariantu pochodzą także z terenu Niemiec ${ }^{7}$ (por. niżej).

Warto przy tym zauważyć, iż opisy części z uwzględnionych w literaturze archeologicznej zabytków omawianego typu są bardzo lakonicznie, np. „nagolenników” z Czerska, pow. chojnicki (Łuka 1966, s. 84-85), Czarnowic, pow. krośnieński (Schacht 1982, s. 103, nr kat. 112) czy Kołobrzegu (Kostrzewski [1951-1952] 1953, s. 201). Często też można się spotkać z założeniem a priori przynależności niektórych znalezisk do wariantu zdobionego (por. np. Skrzypek [1995] 1996, ryc. 1.2), mimo iż w literaturze źródłowej nie podano tak szczegółowych informacji. Z taką sytuacją mamy do czynienia przy kwalifikowaniu ozdób z Mosiny, pow. szczecinecki (Schacht 1982, s. 85) czy Tczewa (Sprockhoff 1956, s. 19). W niektórych przypadkach stan zachowania, np. uszkodzone, niezachowane końce, uniemożliwia bezsporne przyporządkowanie do danego wariantu. To ostatnie zjawisko dotyczy m.in. znalezisk z Mieroszyna i Mosiny (patrz niżej), a także Nowogardu, pow. goleniowski (Kunkel 1932, s. 61).

Pod względem terytorialnym najbliższą analogią do „nagolennika” z okolic Tykocina są dwie ozdoby obręczowe pochodzące ze skarbu z Kalinówki Kościelnej, pow. moniecki (ryc.6). Depozyt ten, znaleziony na początku XX w., zawierał pierwotnie ponad 50 przedmiotów, głównie siekierek (Kostrzewski [1962] 1964, s. 36-38, ryc. 29, tabl.X). Wystąpiły w nim także dwie ozdoby „...otwarte i puste w środku..., okrągłe, z małą szczeliną od wewnątrz, mimo drobnych różnic stylistycznych uznane za analogiczne do okazów ze Słupów, pow. aleksandrowski (Dąbrowski 1997, s. 67, ryc. $39 f)^{8}$. Na podstawie publikowanego rysunku jednej z nich można uznać, iż w porównaniu do egzemplarza z Tykocina mają one znacznie mniejszą średnicę przekroju obręczy.

Wspomniane znalezisko gromadne ze Słupów ${ }^{9}$ odkryto w XIX w. Poza czterema „nagolennikami” zawierało ono - oprócz naszyjników, tarczek i innych ozdób - siekierki, a także czerpak brązowy i sztabki surowca (Szafrański 1955, s. 63, 151, 200-204; Kostrzewski [1962] 1964, s. 68, ryc. 88-90). Omawiane okazy, opisane jako naramienniki, były puste $\mathrm{w}$ środku, niezdobione, o końcach otwartych, ze szparą od spodu widoczną na całej długości (Szafrański 1955, ryc. 334-337; Durczewski [1960] 1961, s. 55-57, ryc. 51: 13-16).

Kolejne wyroby brązowe zaliczane do niezdobionych tzw. nagolenników pustych wewnątrz lokalizowane są w zdecydowanej większości na terenie uznawanym za

${ }^{7}$ Nie można wykluczyć, iż wariant ten występował również w Danii, jednak stan zachowania tak opisywanych egzemplarzy nie pozwala na jednoznaczne przyporządkowanie ich do tego wariantu (por. Schacht 1982, s. 68-69).

${ }^{8}$ Natomiast J. Kostrzewski ([1962] 1964, s. 36) określił je mianem ,...2 nagolenników o przekroju kolistym, litych ze stykającymi się końcami...”

9 Obecnie zamiast miejscowości Słupy funkcjonują bezpośrednio ze sobą sąsiadujące Słupy Duże i Słupy Małe. Ze względu na brak danych dotyczących dokładnej lokalizacji skarbu nie sposób przypisać go jednej z nich. 
As far as the territory is concerned, the closest analogy to the "anklet" from the vicinity of Tykocin are two pieces of ring jewellery from the hoard unearthed in Kalinówka Kościelna, Mońki district (Fig. 6). This deposit, found in the early $20^{\text {th }}$ c., originally consisted of more than 50 items, mostly small axes (Kostrzewski [1962] 1964, pp.36-38, Fig. 29, Pl.X). There were also two pieces of jewellery, "...penannular and hollow...", round, with a small gap on the inner side, regarded as parallels to the specimens from Słupy, Aleksandrów Kujawski district, despite minor stylistic differences (Dąbrowski 1997, p. 67, Fig. 39f) ${ }^{8}$. On the basis of the published drawing of one of them, it can be concluded that they have much smaller diameters of the cross-sections compared to the one from Tykocin.

The aforementioned multiple find from Słupy ${ }^{9}$ was discovered in the $19^{\text {th }} \mathrm{c}$. Apart from four "anklets" it consisted of other jewellery, e.g. neck rings, plates, as well as small axes, a bronze scoop and metal bars (Szafrański 1955, pp. 63, 151, 200-204; Kostrzewski [1962] 1964, p. 68, Figs 88-90). These specimens, described as arm rings, were hollow, undecorated, penannular and had a gap on the inner side running along the whole circumference (Szafrański 1955, Figs 334-337; Durczewski [1960] 1961, pp. 55-57, Fig. 51: 13-16).

A great majority of bronze artefacts identified as undecorated "hollow anklets" were found in the region regarded as the central one for objects of this type - Pomerania. The northernmost site where these artefacts were discovered is Mieroszyno, Puck district. The assemblage, which has been interpreted in many ways, was unearthed in $1882^{10}$. It consisted mainly of jewellery: kidney-shaped bracelets ("Nierenringe"), a bow-shaped neck ring ("Bügelhalsring"), as well as damaged (broken ends) undecorated hollow ring described as an anklet (tuka 1966, p. 261; Schacht 1982, p. 70). The state of preservation of the latter is not sufficient to regard this parallel as a certain one.

Four hollow "anklets" - described as penannular cast arm rings - and a sheet metal neck ring were found in a deposit from Kazimierz Pomorski, Koszalin district. Altogether it consisted of 18 items: parts of a bridle, tools and jewellery (Lachowicz 1978, pp. 12-21, Figs 1.8. and 1.3a-d).

The deposit mentioned above seems to show some analogies to an assemblage from Żelazo, Słupsk district. A hoard consisting of 19 items, including 15 small axes with sleeves as well as jewellery, was unearthed there in 2001. One of the pieces of jewellery - hollow and undecorated - was identified as "...a sheet metal neck ring (ankle? arm ring?)..." (Krzysiak 2006, pp. 195, 201). The author identifies the aforementioned set (arm rings and the neck ring) from Kazimierz Pomorski as closest parallels. According to her, they correspond with each other not only in

${ }^{8}$ J. Kostrzewski ([1962] 1964, p. 36) described them as „...two anklets of a circular cross-section, solid and meeting at the ends..."

${ }^{9}$ At present the village of Słupy does not exist and instead there are two neighbouring villages of Słupy Duże and Słupy Małe. The hoard cannot be associated with one of them due to the lack of data concerning the exact place of discovery.

${ }^{10}$ Initially it was identified as coming from a burial; it was also interpreted as a part of a hoard (Schacht 1982, p. 70; Blajer 2001, p. 363). 
macierzysty dla przedmiotów tego typu - Pomorzu. Najbardziej na północ położona jest miejscowość Mieroszyno, pow. pucki, w której w 1882 r. odkryto różnie interpretowany zespół znalezisk ${ }^{10}$. Pochodziły z niego głównie ozdoby: bransolety nerkowate i naszyjnik kabłąkowaty oraz uszkodzona (odłamane końce) obręcz pusta w środku, niezdobiona, określona jako nagolennik (Łuka 1966, s. 261; Schacht 1982, s. 70). Stan zachowania zabytku nie pozwala uznać tej analogii za pewną.

Cztery „nagolenniki” puste w środku - opisane jako lane naramienniki z otwartymi końcami - oraz naszyjnik z blachy wchodziły także w skład depozytu z Kazimierza Pomorskiego, pow. koszaliński. Ogółem zawierał on 18 przedmiotów: części uprzęży, narzędzia i ozdoby (Lachowicz 1978, s. 12-21, ryc. 1.8. i 1.3a-d).

Z przywołanym wyżej zespołem łączy się w pewien sposób znalezisko z miejscowości Żelazo, pow. słupski. W 2001 r. odkryto tam skarb zawierający łącznie 19 przedmiotów, w tym 15 siekierek z tulejką oraz ozdoby. Jedna z nich - pusta w środku, nieornamentowana - została uznana za ,...naszyjnik (nagolennik? naramiennik?) blaszany..." (Krzysiak 2006, s. 195, 201). Za najbliższe analogie do tego zabytku autorka uważa wspominany już garnitur (naramienniki oraz naszyjnik) z Kazimierza Pomorskiego. Jej zdaniem, wyroby te odpowiadają sobie nie tylko formą, ale i techniką wykonania ${ }^{11}$, co pozostaje w sprzeczności z opinią F. Lachowicza (1978, s. 12), który wyraźnie rozdzielał lane naramienniki i naszyjnik z blachy. Publikowany opis i ilustracje (por. Krzysiak 2006, s. 195, 201, ryc. 7 i 8) nie pozwalają rozstrzygnąć tej kwestii, wydaje się jednak, iż również to znalezisko należy uwzględnić, omawiając tytułowe zagadnienie.

Kolejne stanowisko zlokalizowane jest bardziej na południe, w miejscowości Mosina. W końcu XIX w. znaleziono tam fragmenty określone jako pozostałości niezdobionego nagolennika brązowego pustego wewnątrz i ułamki naszyjnika podłużnie żebrowanego (Kossinna 1915, przypis 1). Również i ten zachowany jedynie częściowo okaz, podobnie jak wymieniony już wyżej egzemplarz z Mieroszyna, ze względu na stan zachowania należy traktować jako analogię z pewnym zastrzeżeniem.

Dalej na południowy zachód znajduje się Brzesko, pow. pyrzycki, gdzie odkryto bogaty depozyt, w którym poza interesującym nas przedmiotem, znajdowały się inne ozdoby (nagolenniki, w tym wariant zdobiony, i bransolety) oraz siekierki wykonane z brązu i żelaza (Kunkel 1931, s. 62, tabl. 71: 6-10; Kostrzewski [1951-1952] 1953, s. 201; Blajer 2001, s. 63, 354, ryc. 27). Okaz z Brzeska jest jednocześnie najbardziej wysuniętym na zachód z polskich znalezisk.

Z Ziemi Lubuskiej, z miejscowości Ciecierzyce, pow. gorzowski, pochodzą trzy egzemplarze, znalezione razem w skarbie, w tym jeden pokryty na końcach żeberkami i grupami kresek. Pod względem wymiarów „nagolennik” niezdobiony jest bliźniaczo podobny do ornamentowanego, natomiast stan zachowania fragmentu

${ }^{10}$ Pierwotnie uznawany za pochodzący z grobu, interpretowany również jako element skarbu (Schacht 1982, s. 70; Blajer 2001, s. 363).

${ }^{11}$ Wbrew opisowi Franciszka Lachowicza wszystkie ozdoby obręczowe znalezione w tym skarbie, a nie tylko „naszyjnik”, miałyby być „...blaszane...”; zdaniem autorki okaz z Żelaza „...wykonany został w technice odlewu z cienkiej blachy brązowej..." (Krzysiak 2006, s. 201). 
terms of the form but also the production technique ${ }^{11}$, which challenges the opinion expressed by Lachowicz (1978, p. 12), who distinguished the cast arm rings from the sheet metal neck ring. The published description and illustrations (cf. Krzysiak 2006, pp. 195, 201, Figs 7 and 8) are insufficient for unequivocal conclusions, nevertheless, it seems that this assemblage should be taken into consideration in the discussion of the subject of this paper.

Another site is located further to the south, in a village of Mosina. Fragments of artefacts described as remains of an undecorated hollow bronze ankle ring and bits of a ribbed neck ring were discovered in the late $19^{\text {th }} \mathrm{c}$. (Kossinna 1915, note 1). This partially preserved specimen, like the aforementioned artefact from Mieroszyno, should also be treated as a parallel with certain reservations due to its state of preservation.

Brzesko, Pyrzyce district, is a site located further southeast, where a rich deposit with other jewellery apart from the item of interest in the context of this paper has been found (anklets, including the decorated variety, bracelets) as well as small bronze and iron axes (Kunkel 1931, p. 62, Pl.71: 6-10; Kostrzewski [1951-1952] 1953, p. 201; Blajer 2001, pp. 63, 354, Fig. 27). The specimen from Brzesko is the westernmost artefact of this kind found in Poland.

Three specimens come from a hoard found in Lubusz Land, in the village of Ciecierzyce, Gorzów Wielkopolski district, including one artefact with ribbed ends, additionally covered with groups of lines. In terms of its dimensions, the undecorated "anklet" is identical to the decorated one, while the state of preservation of the third one is too poor to identify the variety (Kleemann 1976, pp. 117-118, Fig. $9^{12}$; Schacht 1982, p. 99).

The specimen from Danków, Konin district (Kostrzewski 1923, note 314; idem [1962] 1964, p. 29, Fig. 13), discovered as an isolated find in peat, is the southernmost one.

A certain parallel can be detected in the discovery from Janowice, Lębork district. Apart from hollow forms described as "...made of thick sheet metal...", some of which were ornamented, and four kidney-shaped bracelets, this hoard consisted of a hollow undecorated ring with a loop, $15.6-16 \mathrm{~cm}$ in diameter, interpreted as a neck ring (Łuka 1966, p. 165, Pl. XLIII 4). Since the description of the lost artefacts was compiled on the basis of photographs (Łuka 1966, p. 165; cf. Kunkel 1931, Pl. 44), it is difficult to find correspondence in published drawings (Schacht 1982, Pl. 5:30a-c). The fact that it might have been an "anklet" is suggested by a similar specimen, decorated and of a much bigger diameter, recovered from a hoard in Gniewino, Wejherowo district (Kunkel 1931, p. 122, Pl. 43:9; Schacht 1982, Pl. 3:27b).

Perhaps the discussed variety should also include a piece of jewellery from a hoard discovered in Tczew. The literature (Sprockhoff [1949/50] 1950, p. 99)

${ }^{11}$ Regardless of the description by Franciszek Lachowicz, all the ring jewellery found in this hoard, and not only the "necklace" was made of "...sheet metal..."; according to the author, the specimen from Żelazo “...was made of a thin sheet of metal by the casting technique...” (Krzysiak 2006, p. 201).

12 The caption incorrectly states Ulim. 
trzeciego nie pozwala ocenić, do którego wariantu należał (Kleemann 1976, s. $117-$ 118, ryc. $9^{12}$; Schacht 1982, s. 99).

Najdalej na południe wysuniętym znaleziskiem na ziemiach polskich jest odkryty luźno w torfie okaz z Dankowa, pow. koniński (Kostrzewski 1923, przypis 314; tenże [1962] 1964, s. 29, ryc. 13).

Do pewnego stopnia łączy się z omawianymi wyżej odkrycie z Janowic, pow. lęborski. Oprócz opisanych jako „...wykonane z grubej blachy...” form pustych wewnątrz, niektórych ornamentowanych, oraz czterech bransolet nerkowatych, stwierdzono w tym skarbie niezdobioną obręcz z uszkiem, pustą w środku, o średnicy 15,6-16 cm, interpretowaną jako naszyjnik (Łuka 1966, s. 165, tabl. XLIII 4). Ze względu na to, iż podstawą opisu zaginionych zabytków były jedynie fotografie (Łuka 1966, s. 165; por. Kunkel 1931, tabl. 44), trudno odnieść doń publikowane rysunki (Schacht 1982, tabl. 5:30a-c). O tym, że mógł być to „nagolennik” świadczy podobny okaz, zdobiony, o znacznie większej średnicy, pochodzący ze skarbu z Gniewina, pow. wejherowski (Kunkel 1931, s. 122, tabl. 43:9; Schacht 1982, tabl. 3:27b).

Nie można wykluczyć, iż do omawianego wariantu należy zaliczyć także ozdobę ze skarbu z Tczewa. W literaturze (Sprockhoff [1949/50] 1950, s. 99) jest ona enigmatycznie opisywana jako wczesna forma „nagolennika” („ein früher Hohlwulst”). Funkcjonuje także jako „...bransoleta lub nagolennik pusty wewnątrz, otwarta...” bez wzmianki o ornamencie (Łuka 1966, s.396), choć figuruje również na mapie okazów zdobionych (Skrzypek [1995] 1996, ryc. 1.2).

\section{ANALIZA PORÓWNAWCZA}

Porównując rozmiary przywołanych wyżej tzw. nagolenników pustych wewnątrz (tabela 3) można zauważyć, iż średnica zewnętrzna większości z nich oscyluje wokół 10-12 cm. Okazy wielkości tego z okolic Tykocina lub większe są zdecydowanie rzadziej spotykane (Ciecierzyce, Janowice (?), Żelazo (?)). Pod uwagę należy wziąć także średnice przekroju obręczy, bowiem ten wymiar wiąże się z proporcjami danego wyrobu. Już przy wstępnym oglądzie można stwierdzić, że niektóre mają wąskie obręcze w stosunku do ich średnicy, np. okaz z Dankowa, a inne - szerokie, np. ozdoba z Mieroszyna.

Analizując stosunek średnicy zewnętrznej przedmiotu do maksymalnej średnicy przekroju obręczy - czyli sprawdzając, ile razy średnica przekroju mieści się $\mathrm{w}$ średnicy zewnętrznej ${ }^{13}$ można zauważyć pewne prawidłowości. Liczbowe wartości tej cechy są największe w przypadku „nagolennika” z Dankowa, a najmniejsze w egzemplarzu z Mieroszyna. U niektórych okazów wartość ta jest bliźniaczo podobna - takie „pary” tworzą dwa okazy ze Słupów $(8,15)$ oraz dwa z Kazimierza Pomorskiego $(5,5)$. Wszystkie cztery ozdoby z tego ostatniego stanowiska mają zbliżone proporcje (tabela 4 ).

\footnotetext{
12 Podpisano błędnie jako Ulim.

${ }^{13}$ W pomiarach uwzględniono maksymalne wartości poszczególnych wymiarów.
} 
describes it enigmatically as an early form of an "anklet" ("ein früher Hohlwulst"). It is also referred to as "...a penannular bracelet or a hollow shin ring...", without a mention of any decoration (Euka 1966, p. 396), although it is marked on the map of decorated specimens (Skrzypek [1995] 1996, Fig. 1.2).

\section{COMPARATIVE ANALYSIS}

Comparing the dimensions of the aforementioned hollow "anklets" (Table 3), it can be observed that the outer diameters of most range from 10 to $12 \mathrm{~cm}$. Specimens reaching the dimensions of the one from Tykocin or even bigger are much less common (Ciecierzyce, Janowice (?), Żelazo (?)). The diameters of the crosssections of the rings should also be taken into consideration as this dimension is connected with proportions of particular artefacts. Even a preliminary observation is sufficient to notice that some artefacts have narrow rings in proportion to their diameter, e.g. the specimen from Danków, while others - relatively broad, e.g. the piece from Mieroszyno.

Analysis of the outer diameter to maximum diameter of the ring cross-section ratio, that is how many diameters of the cross-section can be contained in the outer diameter; ${ }^{13}$ certain regularities can be noted. The values associated with this feature are the highest in the case of the "anklet" from Danków and the lowest for the specimen from Mieroszyno. For some artefacts these values are identical - such "pairs" are made by two specimens from Słupy (8.15) and two items from Kazimierz Pomorski (5.5). All the four pieces of jewellery from the latter site have comparable proportions (Table 4).

On the basis of this proportion an arbitrary division of the "anklets" can be made: a group with a broad ring (3.02-4.75), intermediate (5.50-5.83) and a narrow one (7.29-9.50). This division is definitely arbitrary - considering that some measurements are approximations or cannot be verified ${ }^{14}$, however, it helps to estimate the level of similarity between certain specimens.

The location of the gap and its width is an important feature connected with the cross-section. In the specimens from Brzesko, Kalinówka, Kazimierz Pomorski, Żelazo (?) and most likely Mieroszyno it runs along the inner surface of the ring; it can only be seen on the "underside" of the artefacts from Słupy. The width of the gap shows some variety (cf. Table 3 ) and can reach from $0.3-0.4 \mathrm{~cm}$ (Tykocin, Słupy) to $1.2 \mathrm{~cm}$ (Kazimierz Pomorski). Comparing other dimensions, it is easy to notice that the width does not correspond with the size of the whole artefact.

The cross-sections of the analysed artefacts are usually round or oval. The discussed group ${ }^{15}$ does not include specimens with D- or C-shaped cross-sections,

\footnotetext{
${ }^{13}$ The measurements represent the maximum values for all dimensions.

${ }_{14}$ This situation is best reflected by the example of the ring from Brzesko - depending on the source of the metric data delivered by various authors the ratio could reach 4 or 7 .

15 Perhaps apart from one case from Kazimierz Pomorski (Lachowicz 1978, Fig. 1.3c).
} 
Na podstawie opisywanej proporcji można arbitralnie wyróżnić grupy „nagolenników" o obręczy szerokiej $(3,02-4,75)$, pośredniej $(5,50-5,83)$ oraz wąskiej $(7,29-9,50)$. Podział ten jest oczywiście umowny - biorąc pod uwagę, iż niektóre pomiary mają charakter przybliżony lub niemożliwy do zweryfikowania ${ }^{14}$, pozwala jednak oszacować stopień podobieństwa poszczególnych okazów.

Ważną cechą związaną z przekrojem jest także umiejscowienie szczeliny i jej szerokość. W egzemplarzach z Brzeska, Kalinówki, Kazimierza Pomorskiego, Żelaza (?) i zapewne Mieroszyna biegnie ona po wewnętrznej stronie obręczy; jedynie w okazach ze Słupów widoczna jest na „spodniej” stronie ozdoby. Szerokość szczeliny jest zróżnicowana (por. tabela 3) i może sięgać od 0,3-0,4 cm (Tykocin, Słupy) do $1,2 \mathrm{~cm}$ (Kazimierz Pomorski). Porównując pozostałe wymiary, łatwo zauważyć, że nie wiąże się ona $\mathrm{z}$ wielkością całego wyrobu.

Kształt przekroju w analizowanych przedmiotach jest zazwyczaj kolisty lub owalny. Szerokość szczeliny nie zakłóca jego kształtu. Raczej nie obserwujemy w omawianym zbiorze ${ }^{15}$ - lub nie mamy na ten temat takich informacji - przekrojów w kształcie liter D i C, charakterystycznych dla niektórych egzemplarzy występujących w wariancie zdobionym.

Większość z przywołanych okazów można zaliczyć do form otwartych, tj. takich, w których pomiędzy końcami obręczy zachowana jest przerwa, np. Kazimierz Pomorski, Słupy, Brzesko, Danków, Janowice (?) i być może Kalinówka ${ }^{16}$. Może być ona różnej wielkości - od kilku do kilkunastu milimetrów.

$\mathrm{W}$ przypadku znaleziska $\mathrm{z}$ okolic Tykocina, mimo że odstęp pomiędzy końcami wynosi jedynie $0,3 \mathrm{~cm}$, również można mówić o formie otwartej. Warto przy tym zauważyć, iż w opisach przynajmniej dwóch zabytków (Danków, Janowice (?)) mowa jest o stykających się końcach, podczas gdy na ilustracjach widoczna jest sytuacja przeciwna (por. Kostrzewski [1962] 1964, s. 29, ryc. 13; Łuka 1966, s. 165, tabl. XLIII 4).

$\mathrm{Na}$ tle przedstawionych analogii tzw. nagolennik z okolic Tykocina wydaje się do pewnego stopnia unikatowy. Wyróżnia go zarówno wielkość, jak i bardzo mała w stosunku do niej szerokość szczeliny oraz najmniejszy spośród omawianych odstęp pomiędzy końcami. Pod względem wielkości i proporcji najbliższy jest mu niezdobiony okaz z Ciecierzyc, a być może także egzemplarz z uszkiem z Janowic (tabela 3). Jednak ze względu na metrykę znalezisk i sposób ich publikacji - całkowity brak lub brak wiarygodnych ilustracji, niekompletność danych metrycznych wszystkich cech - trudno stwierdzić to $\mathrm{z}$ całą stanowczością. Podobne do tykocińskiego proporcje wykazują także okazy z Brzeska i Tczewa, jednak ich średnice zewnętrzne są wyraźnie mniejsze.

Spoza obszaru ziem polskich za najbliższą analogię pod względem formalnym można uznać znalezisko luźne z Hittfeld, district Harburg (Dolna Saksonia), odkryte

${ }^{14}$ Najlepiej tę sytuację obrazuje przykład obręczy z Brzeska - w zależności od danych metrycznych podawanych przez różnych autorów proporcja ta może wynosić 4 albo 7 .

${ }_{15}$ Może poza jednym przypadkiem z Kazimierza Pomorskiego (Lachowicz 1978, ryc. 1.3c)

${ }_{16}$ Z opisu (Dąbrowski 1997, s. 67) wynika, że okaz ten należy do form otwartych, natomiast na podstawie publikowanego rysunku (Dąbrowski 1997, ryc. 39f) można stwierdzić, że końce prawie się ze sobą stykają. 
Tabela 3. Niezdobiony tzw. nagolennik pusty wewnątrz z okolic Tykocina na tle podobnych znalezisk z terenu Polski i Niemiec

\begin{tabular}{|c|c|c|c|c|c|c|}
\hline Stanowisko & $\begin{array}{l}\text { Średnica } \\
\text { zewn. }\end{array}$ & $\begin{array}{l}\text { Średnica } \\
\text { wewn. }\end{array}$ & $\begin{array}{l}\text { Średnica } \\
\text { przekroju }\end{array}$ & $\begin{array}{l}\text { Stosunek średnicy } \\
\text { zewn. do średnicy } \\
\text { przekroju }\end{array}$ & $\begin{array}{l}\text { Szerokość } \\
\text { szczeliny }\end{array}$ & Literatura \\
\hline Tykocin & $15-15,2 \mathrm{~cm}$ & $9-9,2 \mathrm{~cm}$ & $2,9-3,2 \mathrm{~cm}$ & 4,75 & $0,3-0,4 \mathrm{~cm}$ & \\
\hline \multicolumn{7}{|c|}{ Polska } \\
\hline Brzesko & $\begin{array}{l}12,6 \mathrm{~cm}^{*}(1) \\
12 \mathrm{~cm}^{(2)}\end{array}$ & $9 \mathrm{~cm}(1)$ & $\begin{array}{l}1,8 \mathrm{~cm}(1) \\
1,8 \times 3 \mathrm{~cm}(2)\end{array}$ & $\begin{array}{l}7,00 \\
4,00\end{array}$ & & $\begin{array}{l}\text { (1) Dorka 1939, tabl. 37, s. 126; } \\
\text { (2) Schacht 1982, s. } 97, \text { tabl. 15:98b }\end{array}$ \\
\hline Ciecierzyce & $15,6-16 \mathrm{~cm}$ & & $3,3 \times 4,5 \mathrm{~cm}$ & 3,55 & & Schacht 1982, s. 99, bez ryc. \\
\hline Danków & $10-11,4 \mathrm{~cm}^{*}$ & $8-9,4 \mathrm{~cm}^{*}$ & $1,2 \mathrm{~cm}^{*}$ & 9,50 & & Kostrzewski [1962] 1964, s. 29, ryc. 13 \\
\hline Janowice & $15-16 \mathrm{~cm}$ & & & & & Łuka 1966, s. 165 \\
\hline Kalinówka Kościelna & $11,09 \times 12,54 \mathrm{~cm}^{\star}$ & $8,36 \times 9,45 \mathrm{~cm}^{*}$ & $1,45 \times 1,6 \mathrm{~cm}^{\star}$ & 7,83 & & Dąbrowski 1997, s. 67, ryc. 39f \\
\hline Kazimierz Pomorski & $11,6 \mathrm{~cm}$ & $8,4 \mathrm{~cm}$ & $1,4 \times 2 \mathrm{~cm}$ & 5,83 & $0,8 \mathrm{~cm}$ & Lachowicz 1978, s. 12 , ryc. $1.3 \mathrm{a}$ \\
\hline Kazimierz Pomorski & $11 \mathrm{~cm}$ & $8,3 \mathrm{~cm}$ & $1,3 \times 2 \mathrm{~cm}$ & 5,50 & $0,6 \mathrm{~cm}$ & Lachowicz 1978, s. 12 , ryc. $1.3 \mathrm{c}$ \\
\hline Kazimierz Pomorski & $11 \mathrm{~cm}$ & $9 \mathrm{~cm}$ & $2 \mathrm{~cm}$ & 5,50 & $1,2 \mathrm{~cm}$ & Lachowicz 1978, s. 12, ryc. $1.3 \mathrm{~d}$ \\
\hline $\begin{array}{l}\text { Kazimierz Pomorski } \\
\text { (fragm.) }\end{array}$ & $13,1 \mathrm{~cm}$ & $9 \mathrm{~cm}^{*}$ & $1,8 \times 2,3 \mathrm{~cm}$ & 5,69 & & Lachowicz 1978 , s. 12 , ryc. $1.3 \mathrm{~b}$ \\
\hline Mieroszyno (fragm.) & $13 \mathrm{~cm}$ & & $3 \times 4,3 \mathrm{~cm}$ & 3,02 & & Schacht 1982, s. 70, tabl. 3; 26 \\
\hline Słupy & $12,4 \mathrm{~cm} \mathrm{(1)}$ & $8,6-9,1 \mathrm{~cm} \mathrm{(2)}$ & $1,7 \mathrm{~cm} \mathrm{(1)}$ & 7,29 & $0,3-0,4 \mathrm{~cm}$ & $\begin{array}{l}\text { (1) Szafrański 1955, s. 202, ryc. } 334 \text {; } \\
\text { (2) Erzepki 1888, s. 30, tabl. X, ryc. } 5\end{array}$ \\
\hline Słupy & $10,2-10,6 \mathrm{~cm}(1)$ & $7,7-8,8 \mathrm{~cm}(2)$ & $1,3 \mathrm{~cm}(1)$ & 8,15 & & $\begin{array}{l}\text { (1) Szafrański } 1955 \text {, s. } 202 \text {, ryc. } 337 \text {; } \\
\text { (2) Erzepki } 1888 \text {, s. } 30 \text {, tabl. X, ryc. } 6\end{array}$ \\
\hline Słupy & $10,2-10,6 \mathrm{~cm}(1)$ & $7,5-8,1 \mathrm{~cm} \mathrm{(2)}$ & $1,3 \mathrm{~cm}(1)$ & 8,15 & & $\begin{array}{l}\text { (1) Szafrański 1955, s. 202, ryc. 336; } \\
\text { (2) Erzepki 1888, s. 30, tabl. X, ryc. } 7\end{array}$ \\
\hline Słupy & $10,8-11,2 \mathrm{~cm}(1)$ & $8,2-8,8 \mathrm{~cm} \mathrm{(2)}$ & $1,4 \mathrm{~cm}(1)$ & 8,00 & & (1) Szafrański 1955, s. 202, ryc. 335 \\
\hline Tczew & $11 \mathrm{~cm}$ & & $2-2,5 \mathrm{~cm}$ & 4,4 & & $\begin{array}{l}\text { Łuka 1966, s. 396; } \\
\text { Sprockohoff } 1956 \text { - } 2 \text { cm grubości }\end{array}$ \\
\hline Żelazo & $16 \mathrm{~cm}$ & $12,1 \mathrm{~cm}$ & $1,91-2,1 \mathrm{~cm}$ & 7,61 & & Krzysiak 2006, s. 195 , ryc. 7:19 \\
\hline \multicolumn{7}{|c|}{ Niemcy } \\
\hline Dreitzsch (fragm.) & \begin{tabular}{|l|}
$\begin{array}{l}\text { około } 10 \mathrm{~cm} \\
\text { (rekonstruowana) }\end{array}$ \\
\end{tabular} & & $1,9 \times 2,7 \mathrm{~cm}$ & 3,70 & $0,6 \mathrm{~cm}$ & Schacht 1982 , s. $104-105$, tabl. 17:116 \\
\hline Groß Buchholz & $20 \mathrm{~cm}$ & & $5,7 \times 9,5 \mathrm{~cm}$ & 2,10 & $2,0 \mathrm{~cm}$ & Schacht 1982, s. 96 , tabl. 15:95 \\
\hline Hittfeld & $14 \mathrm{~cm}$ & & $2,65 \times 3,35 \mathrm{~cm}$ & 4,17 & $0,5 \mathrm{~cm}$ & Schacht 1982, s. 89, tabl. $12: 73$ \\
\hline Pößeneck-Öpitz & $8,2-8,8 \mathrm{~cm}$ & & $0,8-1,6 \mathrm{~cm}$ & 5,50 & $1,4 \mathrm{~cm}$ & Schacht 1982, s. 105, tabl. 17:117b \\
\hline Triglitz & $8 \mathrm{~cm}$ & & $1,1 \times 1,5 \mathrm{~cm}$ & 5,33 & $0,3-0,45 \mathrm{~cm}$ & Schacht 1982 , s. 95 , tabl. 14:90b \\
\hline
\end{tabular}

Objaśnienia: *wymiary na podstawie publikowanych ilustracji; (1), (2) - według stosownej literatury podanej w tabeli. 
Table 3. The undecorated so-called hollow anklet from the vicinity of Tykocin find contextualized against similar finds from Poland and Germany

\begin{tabular}{|c|c|c|c|c|c|c|}
\hline Site & Outer diameter & $\begin{array}{c}\text { Inner } \\
\text { diameter }\end{array}$ & $\begin{array}{l}\text { Diameter } \\
\text { of section }\end{array}$ & $\begin{array}{l}\text { Outer diameter } \\
\text { to section } \\
\text { diameter ratio }\end{array}$ & $\begin{array}{l}\text { Width } \\
\text { of gap }\end{array}$ & References \\
\hline Tykocin & $15-15.2 \mathrm{~cm}$ & $9-9.2 \mathrm{~cm}$ & $2.9-3.2 \mathrm{~cm}$ & 4.75 & $0.3-0.4 \mathrm{~cm}$ & \\
\hline \multicolumn{7}{|c|}{ Poland } \\
\hline Brzesko & $\begin{array}{l}12.6 \mathrm{~cm}^{*}(1) \\
12 \mathrm{~cm}^{(2)} \\
\end{array}$ & $9 \mathrm{~cm}(1)$ & $\begin{array}{l}1.8 \mathrm{~cm}(1) \\
1.8 \times 3 \mathrm{~cm}(2)\end{array}$ & $\begin{array}{l}7.00 \\
4.00\end{array}$ & & $\begin{array}{l}\text { (1) Dorka 1939, Pl. 37, p. 126; } \\
\text { (2) Schacht 1982, p. 97, Pl. 15:98b }\end{array}$ \\
\hline Ciecierzyce & $15.6-16 \mathrm{~cm}$ & & $3.3 \times 4.5 \mathrm{~cm}$ & 3.55 & & Schacht 1982, p. 99, no Fig. \\
\hline Danków & $10-11.4 \mathrm{~cm}^{*}$ & $8-9.4 \mathrm{~cm}^{*}$ & $1.2 \mathrm{~cm}^{*}$ & 9.50 & & Kostrzewski 1964, p. 29, Fig. 13 \\
\hline Janowice & $15-16 \mathrm{~cm}$ & & & & & Łuka 1966, p. 165 \\
\hline Kalinówka Kościelna & $11.09 \times 12.54 \mathrm{~cm}^{*}$ & $8.36 \times 9.45 \mathrm{~cm}^{\star}$ & $1.45 \times 1.6 \mathrm{~cm}^{*}$ & 7.83 & & Dąbrowski 1997, p. 67, Fig. 39f \\
\hline Kazimierz Pomorski & $11.6 \mathrm{~cm}$ & $8.4 \mathrm{~cm}$ & $1.4 \times 2 \mathrm{~cm}$ & 5.83 & $0.8 \mathrm{~cm}$ & Lachowicz 1978, p. 12, Fig. 1.3a \\
\hline Kazimierz Pomorski & $11 \mathrm{~cm}$ & $8.3 \mathrm{~cm}$ & $1.3 \times 2 \mathrm{~cm}$ & 5.50 & $0.6 \mathrm{~cm}$ & Lachowicz 1978, p. 12, Fig. 1.3c \\
\hline Kazimierz Pomorski & $11 \mathrm{~cm}$ & $9 \mathrm{~cm}$ & $2 \mathrm{~cm}$ & 5.50 & $1.2 \mathrm{~cm}$ & Lachowicz 1978, p. 12, Fig. 1.3d \\
\hline $\begin{array}{l}\text { Kazimierz Pomorski } \\
\text { (fragment) }\end{array}$ & $13.1 \mathrm{~cm}$ & $9 \mathrm{~cm}^{*}$ & $1.8 \times 2.3 \mathrm{~cm}$ & 5.69 & & Lachowicz 1978, p. 12, Fig. 1.3b \\
\hline $\begin{array}{l}\text { Mieroszyno } \\
\text { (fragment) }\end{array}$ & $13 \mathrm{~cm}$ & & $3 \times 4.3 \mathrm{~cm}$ & 3.02 & & Schacht 1982, p. 70, Pl. 3; 26 \\
\hline Słupy & $12.4 \mathrm{~cm} \mathrm{(1)}$ & $8.6-9.1 \mathrm{~cm} \mathrm{(2)}$ & $1.7 \mathrm{~cm} \mathrm{(1)}$ & 7.29 & $0.3-0.4 \mathrm{~cm}$ & $\begin{array}{l}\text { (1) Szafrański 1955, p. 202, Fig. 334; } \\
\text { (2) Erzepki 1888, p. 30, Pl. X, Fig. } 5\end{array}$ \\
\hline Słupy & $10.2-10.6 \mathrm{~cm} \mathrm{(1)}$ & $7.7-8.8 \mathrm{~cm} \mathrm{(2)}$ & $1.3 \mathrm{~cm} \mathrm{(1)}$ & 8.15 & & $\begin{array}{l}\text { (1) Szafrański 1955, p. 202, Fig. 337; } \\
\text { (2) Erzepki 1888, p. 30, Pl. X, Fig. } 6\end{array}$ \\
\hline Słupy & $10.2-10.6 \mathrm{~cm}(1)$ & $7.5-8.1 \mathrm{~cm} \mathrm{(2)}$ & $1.3 \mathrm{~cm}(1)$ & 8.15 & & $\begin{array}{l}\text { (1) Szafrański 1955, p. 202, Fig. 336; } \\
\text { (2) Erzepki 1888, p. 30, Pl. X, Fig. } 7\end{array}$ \\
\hline Słupy & $10.8-11.2 \mathrm{~cm} \mathrm{(1)}$ & $8.2-8.8 \mathrm{~cm} \mathrm{(2)}$ & $1.4 \mathrm{~cm} \mathrm{(1)}$ & 8.00 & & (1) Szafrański 1955, p. 202, Fig. 335 \\
\hline Tczew & $11 \mathrm{~cm}$ & & $2-2.5 \mathrm{~cm}$ & 4.4 & & $\begin{array}{l}\text { Łuka 1966, p. 396; } \\
\text { Sprockohoff } 1956-2 \mathrm{~cm} \text { thick }\end{array}$ \\
\hline Żelazo & $16 \mathrm{~cm}$ & $12.1 \mathrm{~cm}$ & $1.91-2.1 \mathrm{~cm}$ & 7.61 & & Krzysiak 2006, p. 195, Fig. 7:19 \\
\hline \multicolumn{7}{|c|}{ Germany } \\
\hline Dreitzsch (fragment) & $\begin{array}{l}\text { about } 10 \mathrm{~cm} \\
\text { (reconstructed) }\end{array}$ & & $1.9 \times 2.7 \mathrm{~cm}$ & 3.70 & $0.6 \mathrm{~cm}$ & Schacht 1982, pp. 104-105, Pl. 17:116 \\
\hline Groß Buchholz & $20 \mathrm{~cm}$ & & $5.7 \times 9.5 \mathrm{~cm}$ & 2.10 & $2.0 \mathrm{~cm}$ & Schacht 1982, p. 96, Pl. 15:95 \\
\hline Hittfeld & $14 \mathrm{~cm}$ & & $2.65 \times 3.35 \mathrm{~cm}$ & 4.17 & $0.5 \mathrm{~cm}$ & Schacht 1982, p. 89, Pl. 12:73 \\
\hline Pößeneck-Öpitz & $8.2-8.8 \mathrm{~cm}$ & & $0.8-1.6 \mathrm{~cm}$ & 5.50 & $1.4 \mathrm{~cm}$ & Schacht 1982, p. 105, Pl. 17:117b \\
\hline Triglitz & $8 \mathrm{~cm}$ & & $1.1 \times 1.5 \mathrm{~cm}$ & 5.33 & $0.3-0.45 \mathrm{~cm}$ & Schacht 1982, p. 95 , Pl. 14:90b \\
\hline
\end{tabular}

Explanation: ${ }^{\star}$ Dimensions based on published illustrations; (1), (2) - according to relevant literature given in the table. 


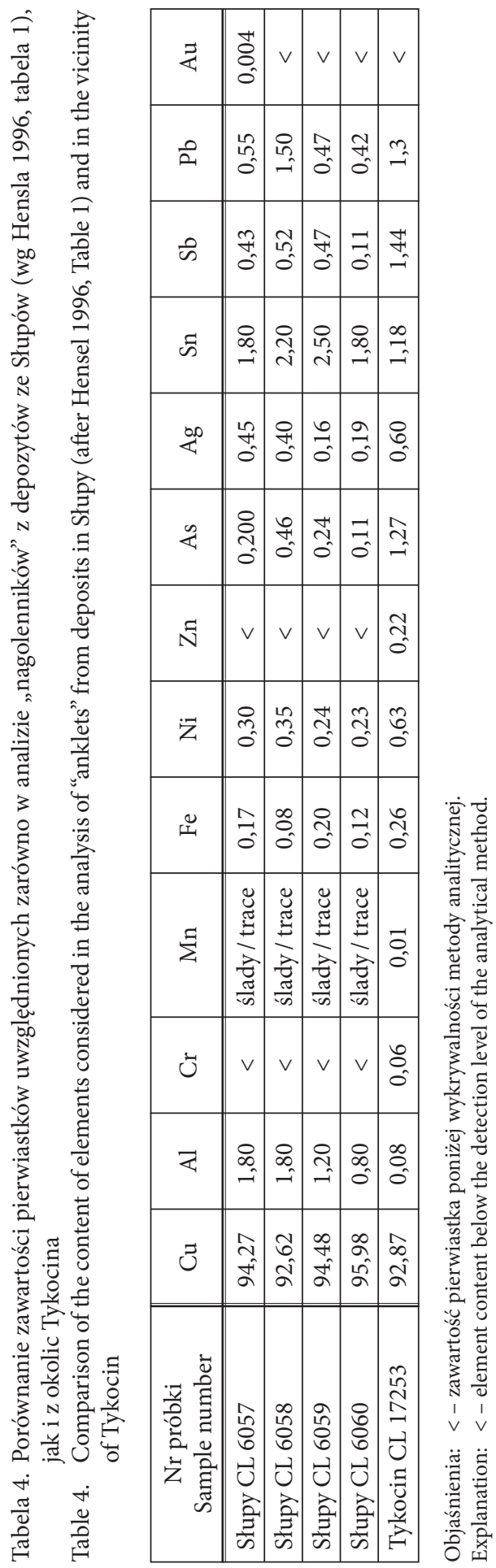


w XIX w. (Schacht 1982, s. 89, tabl. 12:73). W przeciwieństwie do ozdoby z okolic Tykocina ma ono postać całkowicie zamkniętej obręczy ${ }^{17} \mathrm{o}$ średnicy zewnętrznej $14 \mathrm{~cm}$ i przekroju $2,65 \times 3,35 \mathrm{~cm}$ (co daje proporcję 4,17) przy szerokości szczeliny $0,5 \mathrm{~cm}$ (tabela 3).

Okazy z Triglitz, district Prignitz (Brandenburgia) (Schacht 1982, s. 95, tabl. 14:90b) czy Pößeneck-Öpitz, district Saale-Orla (Turyngia) (Schacht 1982, s. 105, tabl. 17:117b) o zamkniętej obręczy są mniejsze nawet od egzemplarzy ze Słupów czy Dankowa. Z kolei "nagolennik” z Groß Buchholz ${ }^{18}$, district Prignitz (Schacht 1982, s. 96, tabl. 15:59) o końcach otwartych jest większy $(20 \mathrm{~cm})$, średnicą zbliżony bardziej do niektórych okazów ornamentowanych oraz do ozdób określanych mianem „naszyjników”, np. z Kazimierza Pomorskiego (por. niżej)

Także wśród wariantu zdobionego dość trudno jest znaleźć ścisły odpowiednik zabytku z okolic Tykocina. Podobnymi wymiarami, z zachowaniem proporcji pomiędzy średnicą zewnętrzną a średnicą przekroju, cechuje się okaz ze skarbu z Janowic, w którym znaleziono także omawiany wyżej egzemplarz bez ornamentu (Schacht 1982, s. 72, tabl. 5:30) oraz tzw. nagolennik wchodzący w skład znaleziska gromadnego z Menkin ${ }^{19}$, district Uckermark (Schacht 1982, s. 92, tabl. 13:84). Na ile można to ocenić na podstawie publikowanych w literaturze informacji, mają one w przybliżeniu kolisty przekrój obręczy, a szerokość szczeliny w przypadku tego ostatniego jest nawet mniejsza niż u okazu z okolic Tykocina. Przypominają go także większe, bo o średnicy sięgającej $24 \mathrm{~cm}$ "nagolenniki” ze skarbu z Gniewina (Kunkel 1931, tabl. 43:9; Schacht 1982, s. 71 tabl. 3:27b) oraz Seddin, district Potsdam-Mittelmark (Schacht 1982, s. 96, tabl. 14:94). Ten ostatni jest zbliżony także szerokością szczeliny równą $0,4 \mathrm{~cm}$.

Przy omawianiu problematyki tzw. nagolenników pustych wewnątrz nie można pominąć także zbliżonych do nich kształtem, niezdobionych przedmiotów opisywanych w literaturze jako „naszyjniki puste wewnątrz”. Dotyczy to m.in. wspominanej już ozdoby z Żelaza oraz analogicznej obręczy ze skarbu z Kazimierza Pomorskiego (Lachowicz 1978, s. 12, 23, ryc. 1.4c), a także dwóch innych znalezisk z Wielkopolski (Durczewski [1960] 1961, s. 54, 72, ryc. 48; 78).

Cechą wspólną wspomnianych tu ozdób jest to, iż w przeciwieństwie do „lanych nagolenników", wszystkie opisywane są jako wykonane z blachy. Wymiary ich średnic zewnętrznych (około 18 i 22,3 cm) ${ }^{20}$ utrzymują się w górnych granicach wielkości charakterystycznych dla tzw. nagolenników pustych wewnątrz, także tych

17 Zakładając, że do omawianego typu ozdób należy zaliczyć także zamknięte okazy puste wewnątrz, można tu przywołać jeszcze „nagolennik” z byłego Trulick z terenu dawnych Prus Wschodnich zblizzony wielkością do tego z Hittfeld $(14 \mathrm{~cm})$, o okrągłym przekroju i ze szczeliną biegnącą od wewnątrz, a uznawany za import z Pomorza (Dąbrowski 1968, s. 80). Brak jednak informacji na temat techniki jego wykonania.

18 Obecnie Groß Buchholz stanowi część miasta Perleberg, district Prignitz.

19 Dawna wieś Menkin stanowi obecnie część miasta Brüssow, district Uckermark.

${ }^{20}$ Wyjątek stanowi zachowany fragmentarycznie okaz z Konojadu, pow. grodziski, przekształcony w bransoletę o średnicy 6,4 cm (Durczewski [1960] 1961, s. 72). Wyróżnia go spośród pozostałych także brak szczeliny, jak wynika z rysunku przekroju, być może mający związek z przeróbką, jakiej został poddany. 
characteristic for some decorated items, or at least there is no information confirming such shapes.

Most the specimens in question can be classified as penannular forms, i.e. which have a gap between the ring ends, for instance the artefacts from Kazimierz Pomorski, Słupy, Danków, Janowice (?) and possibly Kalinówka ${ }^{16}$. The gap could measure from a few to more than ten millimetres.

In the case of the artefact from the vicinity of Tykocin, although the gap between the ends reaches only $0.3 \mathrm{~cm}$, it can be regarded as an open form, like the ones mentioned above. Nevertheless, it should be noted that descriptions of at least two specimens (Danków, Janowice (?)) mention closed ends while the opposite is represented in illustrations (cf. Kostrzewski [1962] 1964, p. 29, Fig. 13; Łuka 1966, p. 165, Pl. XLIII 4).

Compared to the listed parallels, the so-called anklet from the vicinity of Tykocin seems unique to a certain extent. It is distinguished by its dimensions and a very narrow gap as well as the smallest distance between the ends among all the specimens mentioned above. In terms of size and proportions it is closest to the item from Ciecierzyce and possibly the item with a loop from Janowice (Table 3). However, due to the time that has elapsed since the discovery and the manner of publication - lack of any illustrations or lack of reliable representations, incompleteness of metric data concerning all the features - it is difficult to verify this suggestion. Specimens from Brzesko and Tczew show comparable proportions to the ones associated with the Tykocin artefact, but their outer diameters are much smaller.

An isolated find from Hittfeld, district Harburg (Lower Saxony), discovered in the $19^{\text {th }} \mathrm{c}$. (Schacht 1982, p. 89, Pl. 12:73) seems to be the closest analogy with regards to the form that can be found outside Poland. As opposed to the artefact from the vicinity of Tykocin, it has a completely closed ring ${ }^{17}$ with a diameter of $14 \mathrm{~cm}$, a cross-section measuring $2.65 \times 3.35 \mathrm{~cm}$ (ratio 4.17 ) and the width of the gap reaching $0.5 \mathrm{~cm}$ (Table 3 ).

Artefacts from Triglitz, district Prignitz (Brandenburg) (Schacht 1982, p. 95, Pl. 14:90b) and Pößeneck-Öpitz, district Saale-Orla (Thuringia) (Schacht 1982, p. 105, Pl.17:117b) are smaller even than the ones from Słupy and Danków. The penannular "anklet" from Groß Buchholz ${ }^{18}$, district Prignitz (Schacht 1982, p. 96, $\mathrm{Pl} .15: 59)$ is bigger $(20 \mathrm{~cm})$, its diameter is closer to some decorated specimens and jewellery described as "neck rings", e.g. from Kazimierz Pomorski (cf. below).

16 Its description (Dąbrowski 1997, p. 67) suggests that the specimen belongs to the group of open forms, however, on the basis of the published drawing (Dąbrowski 1997, Fig. 39f) it can be concluded that the ends almost meet.

17 Assuming that the discussed group should also include closed hollow specimens, an "anklet" from former Trulick in former East Prussia could be mentioned. It was comparable in terms of size to the one from Hittfeld $(14 \mathrm{~cm})$, had a round cross-section and a gap running along the inner surface, and was regarded as an import from Pomerania (Dąbrowski 1968, p. 80). Nevertheless, information concerning the production technique is not available.

${ }_{18}$ At present Groß Buchholz is a part of the town of Perleberg, district Prignitz. 
zdobionych. Natomiast średnice przekroju obręczy - w dwóch przypadkach wynoszące około $1 \mathrm{~cm}$, zaś w dwóch pozostałych sięgające $2 \mathrm{~cm}$ - są relatywnie wąskie w stosunku do wielkości obwodu. Ta proporcja, zdecydowanie wyższa (18 i 11,5) niż ta potwierdzona dla omawianych „nagolenników”, oraz sposób ich wykonania wskazują na wyraźną odrębność tych wyrobów od omawianego typu zabytków.

\section{SUROWIEC I TECHNIKA WYKONANIA}

Dla znalezisk z terenu Polski dysponujemy pięcioma analizami składu chemicznego, których wyniki pozwolą rzucić nieco światła na skład stopu, z jakiego wykonywano tzw. nagolenniki puste wewnątrz. Jest to jednak liczba zdecydowanie zbyt mała, by móc ustalić jakiekolwiek prawidłowości. Zwłaszcza biorąc pod uwagę nierównomierny rozkład składników w stopie, jak również różnice wynikające z różnorodności stosowanych metod analitycznych (np. Hensel 1996, s. 132).

Badania tego rodzaju przeprowadzono dla okazu z okolic Tykocina i dla zabytków ze Słupów (Hensel 1996, s. 159-160). Wyniki tych analiz zostały zestawione w tabeli 4. Jak można zauważyć, omawiane „nagolenniki” cechuje ponad $90 \%$ udział miedzi oraz niska ilość cyny; oscylująca wokół 2\% (Słupy) lub nawet 1\% (Tykocin). W dwóch okazach można też zaobserwować podwyższoną zawartość ołowiu (1,3 i 1,5\%). Znacząca jest także w okazie z okolic Tykocina przewyższająca $1 \%$ obecność antymonu i arsenu - pierwiastków uważanych za niekorzystne dla właściwości stopu.

Zdaniem Zdzisława Hensla, egzemplarze ze Słupów należą do trzech różnych grup surowcowych wyróżnionych przez tego autora wśród wyrobów brązowych z Kujaw na podstawie głównych czynników stopowych i pierwiastków śladowych (Hensel 1996, tabela 2). Grupy te nie są charakterystyczne dla konkretnych typów przedmiotów czy stopów o określonych właściwościach, nie można ich też zróżnicować chronologicznie ${ }^{21}$ ani łączyć z konkretnymi ośrodkami produkcyjnymi. Wskazują one jedynie kierunek, z jakiego mógł być importowany surowiec (Hensel 1996, s. 138). Ponadto, ze względu na brak podanych kryteriów, jakimi kierowano się przy wydzieleniu grup, nie można odnieść do nich zabytku z okolic Tykocina.

Wobec powyższego wypada ograniczyć się jedynie do skomentowania zawartości procentowej głównych składników stopu, z jakiego wykonywano omawiany typ ozdób, oraz ustosunkować się do obecności pierwiastków występujących w nim w dużej ilości.

Spośród analizowanych wyrobów brązowych z terenu Kujaw większość, zarówno ozdób, jak i narzędzi, np. sierpów, ma udział miedzi przekraczający 90\% (Hensel 1996, tabela 1). Podobną sytuację można zaobserwować w odniesieniu do materiałów z północno-wschodniej Polski, spośród których warto wymienić przytaczany już skarb z Kalinówki Kościelnej (Dąbrowski 1997, zestawienie 8). Zawartość miedzi zbliżoną do tej charakteryzującej „nagolennik” z okolic Tykocina stwierdzono także w „bransolecie” znalezionej w tym samym zespole - 92,7\% (tabela 2), a także

${ }^{21}$ Poza grupą surowcową B1a, którą można wiązać z IV/V EB (Hensel 1996, s. 138). 
It is equally difficult to find parallels for the specimen from the vicinity of Tykocin in the group of decorated artefacts. Comparable dimensions, outer diameter to cross-section diameter ratio can be observed in the item from the Janowice hoard, which also contained the aforementioned undecorated specimen (Schacht 1982, p. 72, Pl. 5:30), and in the so-called anklet from a multiple find from Menkin ${ }^{19}$, district Uckermark (Schacht 1982, p. 92, Pl. 13:84). As far as it can be estimated on the basis of published data, they have a roughly circular ring cross-section and the width of the gap of the latter is even smaller than in the case of the Tykocin artefact. Some larger specimens, with diameters reaching $24 \mathrm{~cm}$, also resemble the discussed item - from the Gniewin hoard (Kunkel 1931, Pl. 43:9; Schacht 1982, p. 71, Pl. 3:27b) and from Seddin, district Potsdam-Mittelmark (Schacht 1982, p. 96, Pl. 14:94). The latter additionally has a comparable gap of $0.4 \mathrm{~cm}$.

The discussion of the so-called hollow anklets cannot omit the undecorated artefacts of a similar shape, described as "hollow neck rings" in the literature. It is relevant in the case of the piece of jewellery from Żelazo, mentioned above, and a parallel ring from the Kazimierz Pomorski hoard (Lachowicz 1978, pp. 12, 23, Fig. 1.4c), as well as two other discoveries from Greater Poland (Durczewski [1960] 1961, pp. 54, 72, Figs 48; 78).

The common trait of this jewellery is the fact that all the items are described as made of sheet metal, as opposed to "cast anklets". Their outer diameters (approx. 18 and $22.3 \mathrm{~cm})^{20}$ are close to the upper values characteristic for the so-called hollow anklets, including the decorated ones. Nevertheless, the diameters of the ring crosssections $-1 \mathrm{~cm}$ in two cases and $2 \mathrm{~cm}$ in the other two - are relatively narrow in proportion to the circumference. This ratio, markedly higher (18 and 11.5) than the one for the discussed "anklets", as well as the manner of production, indicate their evident distinct nature.

\section{RAW MATERIAL AND PRODUCTION TECHNIQUE}

The results of five chemical analyses of discoveries from the Polish territory, which have been conducted so far, shed some light on the composition of the alloys used for production of the so-called hollow anklets. However, this number is far too low to establish any regularities, particularly if we consider the uneven distribution of elements in alloys and differences resulting from application of various analytical methods (e.g. Hensel 1996, p. 132).

The results are listed in table 4 . The "anklets" in question are characterized by a content of more than $90 \%$ of copper and a low content of tin, oscillating around

${ }^{19}$ Formerly the village of Menkin, it is now a part of the town of Brüssow, district Uckermark.

${ }^{20}$ The partially preserved artefact from Konojad, Grodzisk Wielkopolski district, re-shaped into a bracelet of $6.4 \mathrm{~cm}$ in diameter (Durczewski [1960] 1961, p. 72) seems to be an exception. It is additionally distinguished by the absence of the gap, which, as suggested by the drawing, might have resulted from the re-shaping. 


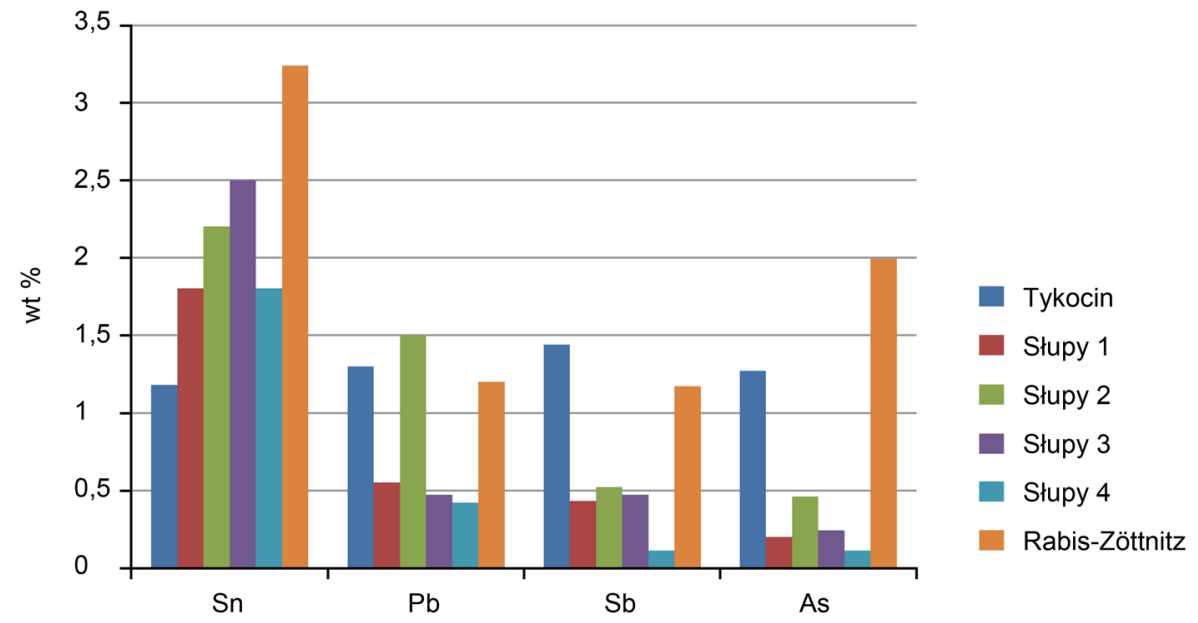

Ryc. 7. Zawartość cyny, ołowiu, antymonu i arsenu w „nagolennikach” z okolic Tykocina, Słupów i Rabis-Zöttnitz.

Opracowała J. Urban

Fig. 7. Tin, lead, antimony and arsenic percentages in "anklets" from the vicinity of Tykocin, Słupy and Rabis-Zöttnitz.

Processing J. Urban

w okazie zdobionym z Rabis-Zöttnitz, district Saale-Holzland, we wschodniej Turyngii - 90,33\%. Przy czym w tym ostatnim zawartość cyny przekracza $2 \%$ (Simon 1972, s. 100, nr kat. 80) ${ }^{22}$.

Niski udział cyny, choć na pozór zastanawiający, również nie jest niczym wyjątkowym, gdyż można go zaobserwować w różnego rodzaju zabytkach o różnej chronologii. Przykładowo, pośród zespołów datowanych na IV/V EB nieco powyżej $1 \%$ tego pierwiastka ma bryłka brązu $(1,13 \%)$ czy fragment sztabki $(1,45 \%)$ z cmentarzyska w Karczynie, pow. inowrocławski (Hensel 1996, s. 156-157), a także zawieszka (1,10\%) i kółka (1,4 i 1,6\%) z cmentarzyska w Radojewicach, pow. inowrocławski (Hensel 1996, s. 157).

W datowanym na VI EB skarbie z Kalinówki Kościelnej spośród 21 siekierek trzy zawierają od $1 \%$ do $1,3 \%$ cyny. Podobny udział stwierdzono w bransolecie $(1,5 \%)$ z Łodzi-Teofilowa (Kaszewski 1973, s. 31, tabela 1) oraz szpili (1,4\%) z Wiciny, pow. żarski (Kaźmierczak i in. 2011, tabela 2). Oba depozyty, w których wystąpiły te znaleziska, pochodzą z HD. Nieco wyższy procent $(1,9 \%)$, zbliżony do „nagolenników" ze Słupów, odnotowano w obręczy owalnej, zdobionej ukośnymi kreskami ze skarbu z HC ze Szczebrzeszyna, pow. zamojski (Nosek, Stępiński 2007, tabela 1).

Z kolei zawartość cyny poniżej $1 \%$ zaobserwowano w naszyjniku o końcach zwiniętych w uszka $(0,83 \%)$ i w brzytwie trapezowatej $(0,09 \%)$ z osady w Siniarzewie, pow. aleksandrowski, stan. 1, datowanej ${ }^{14} \mathrm{C}$ na $1400-1000 / 900$ BC

22 Analiza wykazała, iż egzemplarz ten charakteryzują także porównywalne z okazem tykocińskim zawartości ołowiu 1,2\%, antymonu 1,17\% i arsenu 1,99\% (ryc. 7). 
$2 \%$ (Słupy) or even $1 \%$ (Tykocin). Two specimens display an elevated lead content (1.3 and 1.5\%). Another interesting fact is the significant content (more than 1\%) of antimony and arsenic - elements regarded as harmful for properties of alloys.

According to Zdzisław Hensel, the artefacts from Słupy belong to three different raw material groups, distinguished by this author among bronze items from Kuyavia on the basis of the main ingredients of the alloys as well as trace elements (Hensel 1996, Table 2). These groups are not characteristic for any particular types of objects or alloys of certain defined properties; they cannot be distinguished in terms of their chronology ${ }^{21}$ or associated with particular production centres. They just indicate the direction which the raw material might have been imported from (Hensel 1996, p. 138). Moreover, due to the undefined criteria for the division into these groups, they cannot be applied to the artefact from the vicinity of Tykocin.

For this reason, the only comments should refer to the percentages of the main ingredients of the alloys and the presence of the elements which constitute their major contents.

The majority of the analysed bronze artefacts from Kuyavia, both the jewellery and the tools, e.g. sickles, were made of an alloy with more than $90 \%$ of copper (Hensel 1996, Table 1). A similar situation can be observed in the case of materials from north-eastern Poland, for instance the Kalinówka Kościelna hoard mentioned above (Dąbrowski 1997, List 8). The copper content which is comparable with the one in the Tykocin "anklet" was detected in the "bracelet" from the same assemblage - 92.7\% (Table 2), as well as in a decorated artefact from Rabis-Zöttnitz, district Saale-Holzland, eastern Turingia $-90.33 \%$. The tin content in the latter one exceeds 2\% (Simon 1972, p. 100, cat. no. 80) ${ }^{22}$.

A low content of tin, although apparently surprising, is not unusual as it has been detected in various artefacts of diverse chronologies. For instance, the following items from IV/V EB assemblages exceed 1\% tin content: a small lump of bronze $(1.13 \%)$ and a fragment of an ingot $(1.45 \%)$ from a cemetery in Karczyn, Inowrocław district (Hensel 1996, pp. 156-157), a pendant (1.10\%) and rings (1.4 and 1.6\%) from a cemetery in Radojewice, Inowrocław district (Hensel 1996, p. 157).

Three out of 21 small axes from the Kalinówka Kościelna hoard from VI BA contain between $1 \%$ and $1.3 \%$ of tin. A similar content was detected in a bracelet from Łódź-Teofilów (Kaszewski 1973, p. 31, Table 1) and a pin (1.4\%) from Wicina, Żary district (Kaźmierczak et al. 2011, Table 2). Both deposits with these finds are dated to HD. A slightly higher content (1.9\%), corresponding with the "anklets" from Słupy, was found in an oval ring decorated with diagonal lines - an artefact from a HC hoard from Szczebrzeszyn, Zamość district (Nosek, Stępiński 2007, Table 1).

Tin content below $1 \%$ was detected in a neck ring with ends folded into loops $(0.83 \%)$ and a trapezoid razor $(0.09 \%)$ from a settlement in Siniarzewo, Aleksandrów

${ }^{21}$ Apart from the raw material group B1a, which could be associated with IV/V EB (Hensel 1996, p. 138).

${ }^{22}$ Chemical analysis detected the following percentages of: lead $-1.2 \%$, antimony $-1.17 \%$ and arsenic $-1.99 \%$ in this artefact, which are comparable to the ones found in the specimen from Tykocin (Fig. 7). 
(Cofta-Broniewska 2004, s. 450), jak również w jednej z ozdób obręczowych (0,92\%) ze skarbu z jeziora Gopło, pow. inowrocławski, pochodzącego z HD (Hensel 1996, s. 161, gdzie figuruje jako naramiennik).

Omawiany pierwiastek wpływa korzystnie na własności mechaniczne stopu. Odlewy o zawartości $10 \%$ cyny od czasów rzymskich uważano za najlepsze, ale już wyroby o udziale 6-8\% mają optymalne cechy wytrzymałościowe. Z kolei brąz o zawartości 2-4\% Sn uznawany jest za stop przeznaczony do obróbki plastycznej (Hensel 1996, s. 148-149, 151). Zdaniem Jana Dąbrowskiego (1997, s. 123) mała ilość cyny może być wynikiem utleniania się tego pierwiastka podczas kolejnego topienia surowca. Udział wysokości 1-1,2\% Sn sprawia, iż wyrób należy właściwie uznać za wykonany z miedzi, a jego walory użytkowe są obniżone.

Dwojaki wpływ na jakość brązu ma obecność ołowiu. Z jednej strony korzystnie działa on na lejność stopu (podniesienie cech odlewniczych), z drugiej oddziałuje ujemnie na jego cechy wytrzymałościowe (Hensel 1996, s. 149, 151). W zabytkach z wczesnej epoki żelaza jego udział zazwyczaj nie przekracza 1\% (por. np. Chomentowska 1960, s. 505; Nosek, Stępiński 2007, tabela 1; Kaźmierczak i in. 2011, tabela 2). Procentowa zawartość tego pierwiastka w wysokości odpowiadającej tej, jaka wystąpiła w „nagolenniku” z okolic Tykocina $(1,3 \%)$ lub wyższa obserwowana jest rzadko. Zbliżone udziały $(1,2-1,92 \%$ oraz $1-1,3 \%)$ stwierdzono, np. w niektórych przedmiotach z Wiciny (Kaźmierczak i in. 2011, tabela 2) i Kalinówki Kościelnej (Dąbrowski 1997, zestawienie 8). Jedna z siekierek znaleziona $\mathrm{w}$ tym ostatnim depozycie zawierała nawet $4,5 \%$ ołowiu, podobnie jak naszyjnik $(5,0 \%)^{23} \mathrm{z}$ datowanego na HD skarbu $\mathrm{z}$ Drohiczyna, pow. siemiatycki (Andrzejowska 2007, przypis 12$)$.

W przypadku „nagolennika” z okolic Tykocina zwraca uwagę także zbliżony, wysoki udział antymonu i arsenu (1,44\% Sb, 1,27\% As) przekraczający zawartość cyny (tabela 2). Oba te pierwiastki uważane są za niekorzystne dla stopu, zwłaszcza jeśli jest on przeznaczony do obróbki plastycznej (Hensel 1996, s. 133, 151). Taka ich ilość plasuje omawiany zabytek pomiędzy dwiema wyróżnionymi przez Z. Hensla (1996, s. 149) grupami surowcowymi: B1 i B1a. W pierwszej graniczne wartości są nieco niższe (do 1,2\% As i do 1,15\% Sb), w drugiej - wyższe (1,7\% As i 2,2\% Sb).

Podobny do tykocińskiego lub wyższy udział antymonu stwierdzono w grocie $(1,4 \%)$ i siekierce $(1,8 \%)$ ze skarbu ze Szczebrzeszyna (Nosek, Stępiński 2007, tabela 1), a także w grocie (2\%) z osady w Maciejowicach, pow. garwoliński (Mogielnicka-Urban 2014, s. 111), oraz kilku siekierkach (1-2\%) z Kalinówki Kościelnej (Dąbrowski 1997, zestawienie 8). Zdecydowanie więcej tego pierwiastka odnotowano w ukośnie żłobkowanym naszyjniku o końcach zwiniętych w uszka $(3,88 \%)$ ze wzmiankowanej już osady w Siniarzewie (Cofta-Broniewska 2004, s. 450). Natomiast zbliżoną ilość arsenu zaobserwowano np. w grocie $(1,17 \%)$ ze skarbu z Wiciny (Kaźmierczak i in. 2011, tabela 2) czy wymienionej już siekierce $(1,2 \%)$ ze Szczebrzeszyna. Otwarta bransoleta ze sztaby, zdobiona guzkami, z tego ostatniego zespołu zawierała 1,8\% As (Nosek, Stępiński 2007, tabela 1). Wysokie udziały

${ }^{23}$ Przy udziale cyny przewyższającym udział ołowiu, co wyklucza uznanie stopu za brąz ołowiowy. 
Kujawski district, site 1, radio-carbon dated to 1400-1000/900 BC (Cofta-Broniewska 2004, p. 450), as well as in a piece of ring jewellery (0.92\%) from the Lake Gopło hoard (Inowrocław district), dated to HD (Hensel 1996, p. 161 described as an arm ring).

Tin has a beneficial effect on mechanical properties of alloys. Alloys with $10 \%$ of tin have been regarded as the best since Roman times, but even 6-8\% tin content ensures optimal endurance properties. Bronze with $2-4 \%$ tin content is regarded as a good alloy for forming processes (Hensel 1996, pp. 148-149, 151). According to Jan Dąbrowski (1997, p. 123), a low percentage of tin could result from oxidation of this element in the course of repeated melting of this material. Artefacts with tin content of $1-1.2 \%$ should practically be regarded as made of copper and their performance properties are compromised.

Lead content has both advantages and disadvantages. On one hand, it increases alloy castability (it is easier to cast), on the other hand, it reduces alloy endurance (Hensel 1996, pp. 149, 151). Its percentage in Early Iron artefacts does not usually exceed 1\% (cf. e.g. Chomentowska 1960, p. 505; Nosek, Stępiński 2007, Table 1; Kaźmierczak et al. 2011, Table 2). The percentage of this element detected in the Tykocin "anklet" (1.3\%) or even higher is rare. A comparable lead content $(1.2-1.92 \%$ and $1-1.3 \%)$ was found e.g. in some items from Wicina (Kaźmierczak et al. 2011, Table 2) and Kalinówka Kościelna (Dąbrowski 1997, List 8). One of the small axes found in the latter deposit contained as much as $4.5 \%$ of lead, a similar percentage to a neck ring $(5.0 \%)^{23}$ from an HD hoard from Drohiczyn, Siemiatycze district (Andrzejowska 2007, note 12).

High and comparable percentages of antimony and arsenic $(1.44 \% \mathrm{Sb}, 1.27 \%$ As) exceeding the tin content (Table 2) detected in the "anklet" from the vicinity of Tykocin seem atypical. Both elements are regarded as unfavourable for alloy properties, especially if it is used for forming processes (Hensel 1996, pp. 133, 151). Such content places the artefact somewhere in between two raw material groups distinguished by Hensel (1996, p. 149): B1 and B1a. In the former the limit values are slightly lower (up to $1.2 \%$ As and up to $1.15 \% \mathrm{Sb}$ ), and in the latter - higher (1.7\% As and $2.2 \% \mathrm{Sb})$.

A comparable or higher antimony content was detected in a spearhead (1.4\%) and a small axe (1.8\%) from the Szczebrzeszyn hoard (Nosek, Stępiński 2007, Table 1), in a spearhead from a settlement in Maciejowice, Garwolin district (MogielnickaUrban 2014, p. 111), and in a few small axes (1-2\%) from Kalinówka Kościelna (Dąbrowski 1997, List 8). A much higher percentage was detected in a diagonally ribbed neck ring with ends folded into loops (3.88\%) from the aforementioned settlement in Siniarzewo (Cofta-Broniewska 2004, p. 450). A similar content of arsenic was detected e.g. in a spearhead (1.17\%) from the Wicina hoard (Kaźmierczak et al. 2011, Table 2) and the already mentioned small axe (1.2\%) from Szczebrzeszyn. A penannular bar bracelet decorated with knobs from the latter deposit contained 1.8\%

${ }^{23}$ However, the tin content was higher than lead content, which means the alloy cannot be regarded as lead bronze. 
arsenu stwierdzono także w dwóch siekierkach (1,5 i 2,2\%) z Kalinówki Kościelnej (Dąbrowski 1997, zestawienie 8) oraz w przywoływanym już „nagolenniku” (1,99\%) z Rabis-Zöttnitz (Simon 1972, s. 100).

Dane te wskazują, iż znacząca obecność pierwiastków „szkodliwych” dla właściwości stopu w poszczególnych wyrobach nie wykluczała ich walorów użytkowych. Niektórzy badacze zauważają, iż występowanie arsenu, a także żelaza, w wyrobach brązowych jest pochodną obecności tych pierwiastków w rudach miedzi, np. bornicie (Nosek, Stępiński 2007, s. 392; Kaźmierczak i in. 2011, s. 311). Stopień zanieczyszczenia mógł więc być skutkiem użycia danej rudy.

Zawartość cyny i ołowiu w "nagolenniku” z okolic Tykocina wskazywałaby na wykonanie go z brązu przeznaczonego do obróbki plastycznej, jednak wysoka obecność antymonu i arsenu zdaje się temu przeczyć (por. Hensel 1996, s. 155).

Znaleziska z terenu Polski nie dostarczyły, jak do tej pory, bezspornych przesłanek dotyczących techniki wykonania zabytków omawianego typu, choć od dawna przyjmowano iż były one „...odlewane naokoło jądra glinianego...” (Kostrzewski 1923, s. 82, ryc. 286). Najbardziej szczegółowy opis tego procesu dotyczy okazów ze Słupów. Wynika z niego, że zostały one odlane „....wokół rdzenia glinianego, który wydłubano po odlaniu okazu przez szczelinę $4 \mathrm{~mm}$ szeroką, biegnącą spodem..." (Szafrański 1955, s. 202). Większość z przytaczanych wyżej znalezisk jest zazwyczaj opisywana jako ozdoby lane (por. np. Lachowicz 1978, s. 12), choć można spotkać także nieliczne wzmianki o wytwarzaniu ich z blachy brązowej (Łuka 1966, s. 165; Krzysiak 2006, s. 201).

Potwierdzenie tezy o odlewaniu „nagolenników” przynoszą materiały z terenów położonych na zachód od Odry. Dotyczy to zarówno okazów niezdobionych, jak i ornamentowanych. Do tych pierwszych należą wspominane wcześniej egzemplarze z Hittfeld i Gross Bucholz - w obu stwierdzono pozostałości glinianego jądra (Schacht 1982, s. 96). Spośród drugiej grupy wymienić można okazy np. z Dreitzsch, district Saale-Orla (Simon 1972, tabl.27:21) czy Pößeneck-Öpitz (Simon 1972, tabl. 29:25). W tym pierwszym poza rdzeniem zachowały się także pęcherze gazowe powstałe w trakcie odlewania (Schacht 1982, s. 105). Na ostatnim $\mathrm{z}$ wymienionych stanowisk stwierdzono także fragmenty glinianych form niszczejących, nie ma jednak pewności do wyrobu jakiego rodzaju ozdób obręczowych były wykorzystywane (por. Simon 1972, tabl.31:1-2; Schacht 1982, s. 105). Za pozostałości formy „na wosk tracony”, służącej do wyrobu tzw. nagolenników pustych wewnątrz, zostały uznane szczątki glinianego przedmiotu z osady Flædmose w Danii (Thrane 1980, za: Schacht 1982, s. 107).

Szczegółowy proces wytwarzania omawianych wyrobów przedstawia Sigrid Schacht (1982, s. 23-25, ryc. 2). Pierwszym krokiem było wykonanie glinianego rdzenia i powleczenie go woskiem. Na tym etapie modelowano też plastyczne motywy ornamentu. Następnie całość oblepiano gliną. Tak przygotowaną formę wypalano w temperaturze około $700^{\circ} \mathrm{C}$, aby m.in. usunąć wosk. Kolejną czynnością było wlanie stopu, a następnie rozbicie zewnętrznej części formy. Ornamenty puncowane lub ryte nanoszono w dalszej kolejności. Na końcu wykruszano rdzeń poprzez krańcowe otwory lub szczelinę. 
of arsenic (Nosek, Stępiński 2007, Table 1). High arsenic content was also detected in two small axes (1.5 and 2.2\%) from Kalinówka Kościelna (Dąbrowski 1997, List 8) and the "anklet" (1.99\%) from Rabis-Zöttnitz (Simon 1972, p. 100) mentioned above.

These data indicate that the significant content of "harmful" elements in alloys used for production of these artefacts did not destroy their functional properties. Some scholars observe that the presence of arsenic and iron in bronze artefacts is a consequence of the presence of these elements in copper ores, e.g. bornite (Nosek, Stępiński 2007, p. 392; Kaźmierczak et al.2011, p. 311). Thus the degree of contamination might have resulted from the use of particular ores.

The content of tin and lead in the "anklet" from the vicinity of Tykocin should indicate that it was made of a bronze variety used for forming processes, however, the high percentages of antimony and arsenic seem to contradict this (cf. Hensel 1996, p. 155).

Source material from Poland has not yet delivered unquestionable arguments concerning production techniques associated with these artefacts, although it has been accepted that they were "...cast around a clay core..." (Kostrzewski 1923, p. 82, Fig. 286). The most detailed description of this process is connected with the specimens from Słupy. It states that they were cast "....around a clay core which was removed after the specimen was cast through an opening reaching a width of $4 \mathrm{~mm}$, located at the bottom..." (Szafrański 1955, p. 202). Most of the artefacts mentioned above are usually described as cast jewellery (cf. e.g. Lachowicz 1978, p.12), although there also some reports of a production technique using sheet bronze (Łuka 1966, p. 165; Krzysiak 2006, p. 201).

The hypothesis that "anklets" were cast is supported by sources from the territory located to the west of the Oder River. This is relevant both for undecorated and decorated artefacts. The former are represented by the already mentioned specimens from Hittfeld and Groß Bucholz - in both there were remains of a clay core (Schacht 1982, p. 96). The other group includes artefacts from e.g. Dreitzsch, district Saale-Orla (Simon 1972, Pl.27:21) and Pößeneck-Öpitz (Simon 1972, Pl. 29:25). Gas bubbles which formed in the course of casting were preserved in the former, in addition to the remains of the clay core (Schacht 1982, p. 105). Fragments of deteriorating clay moulds were also found at the latter of the sites, however, it is uncertain what type of ring jewellery might have been made in these moulds (cf. Simon 1972, Pl.31:1-2; Schacht 1982, p. 105). Remains of a clay object from a settlement at Flædmose in Denmark (Thrane 1980, after: Schacht 1982, p. 107) were identified as fragments of a "lost-wax casting" mould, which was used for making the so-called hollow anklets.

Details of the process of production associated with the artefacts in question are presented by Sigrid Schacht (1982, pp. 23-25, Fig. 2). The first step was the making of the clay core and covering it with wax. The decoration motifs were shaped at this stage. Then it was covered with clay and the mould was fired at approx. $700^{\circ} \mathrm{C}$, e.g. to remove the wax. The next step was pouring of the alloy into the mould and then smashing of its external part. Punched or incised ornaments were made in the next step. Finally, the core was removed through terminal openings or a gap. 


\section{WARUNKI DEPONOWANIA „NAGOLENNIKÓW”}

Można zauważyć, iż omawiany typ ozdób pochodzi przede wszystkim ze skarbów ${ }^{24}$ deponowanych $\mathrm{w}$ różnych warunkach i okolicznościach, które odkrywane były na ogół bez żadnej osłony (Brzesko, Mosina, Żelazo), np. podczas orki, wyjątkowo pod kamieniem (Ciecierzyce) czy w naczyniu (Kalinówka). Część z nich można z pewną dozą prawdopodobieństwa uznać za depozyty akwatyczne, jak te znalezione na terenie osuszanego jeziora (Kazimierz Pomorski) czy w torfie (Danków). Okolicznościami znalezienia nawiązuje do nich okaz z okolic Tykocina. $\mathrm{Z}$ czterech przywoływanych znalezisk $\mathrm{z}$ terenów położonych na zachód od Odry jedno jest znaleziskiem luźnym, dwa pochodzą z cmentarzysk - z grobu lub obszaru nekropolii, jedno zaś z osady („Hohensiedlung”).

\section{DATOWANIE}

Większość z omawianych tzw. nagolenników pustych wewnątrz datowana jest na HC (Szafrański 1955, s. 151; Durczewski [1960] 1961 s. 55; Lachowicz 1978, s. 31-32; Blajer 2001, s. 355, 356; Krzysiak 2006, s. 203). Dotyczy to zarówno okazów znalezionych na Pomorzu (Kazimierz Pomorski, Mosina, Żelazo), jak i poza nim (Słupy). Przez niektórych badaczy są wręcz uważane za formy przewodnie dla tego okresu (np. Lachowicz 1978, s. 31), aczkolwiek nie wyklucza się ich wykształcenia i funkcjonowania już w V EB (Kostrzewski 1923, s. 82; Durczewski [1960] 1961, s. 91; Lachowicz 1978, s. 24; Dąbrowski 1997, s. 67). Na podstawie określenia chronologii niektórych zespołów, w których wystąpiły, np. skarbów z Mieroszyna, Tczewa, Janowic, a być może także Brzeska ${ }^{25}$ i Ciecierzyc ${ }^{26}$, na okres późniejszy, tj. HD (Łuka 1966, s. 165, 396; Blajer 2001, s. 360, 363, 367), należy sądzić, iż mogły być używane dłużej.

Datowanie skarbu z Kalinówki, a co za tym idzie i „nagolennika”, na VIEB, zgodnie z przyjętym dla terenów Polski północno-wschodniej systemem periodyzacyjnym (Dąbrowski 1997, s. 67), można synchronizować z prezentowanym wyżej.

$\mathrm{Na}$ podstawie przytoczonych analogii okaz z okolic Tykocina również należy łączyć $\mathrm{z}$ HC. Taka periodyzacja pozostaje w zgodzie z chronologią przyjmowaną dla „bransolet” z zachodzącymi końcami (V EB-HC), z których jedna wchodziła w skład omawianego zespołu.

${ }^{24}$ Za depozyt grobowy, zapewne z powodu znalezienia w obrębie lub w pobliżu uszkodzonej skrzyni kamiennej, uznano pierwotnie nagolennik z Mieroszyna (Schacht 1982, s. 70). Trudno także, pomimo funkcjonujących w literaturze sugestii (por. Bukowski 1998, s. 27), uznać za skarb pojedyncze, luźne znalezisko z Dankowa.

${ }^{25}$ Łączony z późną fazą wczesnej epoki żelaza (Kostrzewski 1958, s. 190) lub HC (Lachowicz 1978, s. 22; Blajer 2001, s. 354).

${ }^{26}$ Datowany według różnych autorów na HC (Kleemann 1976, s. 119), HD (Griesa 1982, s. 181) lub HC-D (Blajer 2001, s. 370). 


\section{CONDITIONS OF DEPOSITION OF “ANKLETS"}

It can be noted that the discussed type of jewellery mostly comes from hoards ${ }^{24}$ deposited in different conditions and circumstances, which were usually discovered without any additional cover or protection (Brzesko, Mosina, Żelazo), e.g. in the course of tilling, in exceptional conditions under a stone (Ciecierzyce) or in a pot (Kalinówka). Some of them can be identified as aquatic deposits with a high degree of probability, for instance the ones discovered in a drained lake (Kazimierz Pomorski) or in peat (Danków). The artefact from the vicinity of Tykocin corresponds with them in terms of the circumstances of discovery. Among the four finds in the area situated to the west of the Oder River, one is an isolated find, another two come from cemeteries - from a grave or an area of a necropolis, and one from a settlement ("Hohensiedlung").

\section{CHRONOLOGY}

Most of the discussed so-called hollow anklets are dated to HC (Szafrański 1955, p. 151; Durczewski [1960] 1961 p. 55; Lachowicz 1978, pp. 31-32; Blajer 2001, pp. 355, 356; Krzysiak 2006, p. 203). It is relevant both for the artefacts from Pomerania (Kazimierz Pomorski, Mosina, Żelazo) and outside of this territory (Słupy). Some scholars even regard them as indicator forms for this period (e.g. Lachowicz 1978, p. 31), however, their emergence and use might even date back to V EB (Kostrzewski 1923, p. 82; Durczewski [1960] 1961, p. 91; Lachowicz 1978, p. 24; Dąbrowski 1997, p. 67). On the basis of the established chronology of some assemblages, e.g. the hoards from Mieroszyno, Tczew, Janowice and possibly also Brzesko $^{25}$ and Ciecierzyce ${ }^{26}$, associated with more recent times, i.e. HD (Łuka 1966, pp. 165, 396; Blajer 2001, pp. 360,363,367), it should be concluded that they functioned for an extended period.

The chronology of the Kalinówka hoard and the "anklet" placed in VI EB can be synchronized with the one presented above in accordance with a chronology system accepted for the area of north-eastern Poland (Dąbrowski 1997, p. 67).

On the basis of the parallels described above, the Tykocin specimen can also be associated with HC. Such chronology corresponds with the one accepted for "bracelets" with overlapping ends (V EB-HC), and such artefact was found in the Tykocin assemblage.

${ }^{24}$ The anklet from Mieroszyno was initially identified as a burial deposit, possibly due to its discovery in or in the vicinity of a damaged stone chest (Schacht 1982, p. 70). It is also difficult to identify the isolated find from Danków as a hoard deposit, despite the suggestions in the literature (cf. Bukowski 1998, p. 27).

${ }^{25}$ It is associated with the late phase of the Early Iron Age (Kostrzewski 1958, p. 190) or HC (Lachowicz 1978, p. 22; Blajer 2001, p. 354).

${ }^{26}$ Dated by different authors to HC (Kleemann 1976, p. 119), HD (Griesa 1982, p. 181) or HC-D (Blajer 2001, p. 370). 


\section{POCHODZENIE}

Pochodzenie tzw. nagolenników pustych wewnątrz, w tym niezdobionych, nie budziło dotąd sporów. Zazwyczaj uważano je za charakterystyczne dla terenów położonych na zachód od Wisły wzdłuż południowych wybrzeży Morza Bałtyckiego i wytwarzane lokalnie (Szafrański 1955, s. 63, 151; Kostrzewski 1958, s. 194; Durczewski [1960] 1961, s. 91; Lachowicz 1978, s. 31). W materiałach archeologicznych z terenu Pomorza nie odnotowano wprawdzie znalezisk, które można by łączyć $\mathrm{z}$ wytwarzaniem tego typu przedmiotów, jednak może być to związane ze stanem badań - większość z omawianych „nagolenników” odkryto poza obrębem osad. Rozprzestrzenienie pozostałości form glinianych i „półwyrobów” (okazy z jądrem w środku) wskazuje, iż część z omawianych ozdób była wytwarzana także na zachód od Odry. Ze względu na to, iż wszystkie mają zbliżoną chronologię, przypadającą pomiędzy HC a HD, trudno jest określić jednoznacznie kierunek przepływu tych wytworów. Biorąc pod uwagę, iż jedno z takich odkryć pochodzi z Danii, można przypuszczać, iż pewną rolę odegrał przy tym impuls z północy, co sugerowano już w literaturze (Lachowicz 1978, s. 22).

Okazy spotykane poza obszarem macierzystym, jak np. ze Słupów, Dankowa czy Kalinówki, uważane są za importy, prawdopodobnie z Pomorza (np. Durczewski [1960] 1961, s. 91; Cofta-Broniewska 1996, s. 49; Dąbrowski 1997, s. 67). Omawiany "nagolennik" z okolic Tykocina należy więc traktować jako przedmiot o proweniencji pomorskiej, tak w sensie terytorialnym, jak i kulturowym, gdyż właśnie z tego obszaru pochodzi najwięcej analogii.

Okolice Tykocina, a szerzej rejon pomiędzy Narwią a Biebrzą, zajmowały u schyłku epoki brązu lokalne ugrupowania tzw. kultury łużyckiej. Przyjmuje się wprawdzie, iż mogły one prowadzić miejscową produkcję brązowniczą (Dąbrowski 1997, s. 95, 120, mapa 11; Blajer 2001, s. 296; Pawlata [2011-2012] 2012, s. 29-30, 34 ), jednak przesłanki po temu są dosyć nikłe i słabo udokumentowane ${ }^{27}$. Znacznie lepiej poświadczone jest funkcjonowanie miejscowych warsztatów metalurgicznych dla terenów położonych na północny zachód od Tykocina w odniesieniu do stanowisk datowanych w większości na okres późniejszy - HD (Hoffmann 2000, s. 175-176).

Trudno zatem uznać „nagolennik” tykociński za przejaw rodzimej wytwórczości, zwłaszcza że ten rodzaj znalezisk jest raczej odosobniony (Kalinówka). Należy przyjąć, iż trafił w okolice miejsca późniejszego znalezienia drogą wymiany. Nie sposób stwierdzić, czy został przetransportowany nad Narew bezpośrednio z Pomorza, czy też via ośrodek kujawski. O wzajemnych kontaktach pomiędzy tymi terenami, a także Mazowszem, świadczą również inne znaleziska, m.in. skarb odkryty w Brańsku, pow. bielski (Jaskanis 1976; Mogielnicka-Urban 2008). Niektórzy badacze

${ }^{27}$ Z kilku znalezisk form odlewniczych (Dąbrowski 1997, mapa 11) jedno z całą pewnością zostało zweryfikowane negatywnie (Młodecka, Urban, Maik 2006-2007), a informacje dotyczące pozostałych pochodzą na ogół z badań AZP lub ze sprawozdań z prac terenowych, a zatem ich interpretacja może mieć wstępny charakter. 


\section{PROVENANCE}

The provenance of the so-called hollow anklets, including the undecorated variety, has not been a subject of dispute so far. They were usually regarded as characteristic for the territory located to west of the Vistula River, along the southern coast of the Baltic Sea, and produced locally (Szafrański 1955, pp. 63, 151; Kostrzewski 1958, p. 194; Durczewski [1960] 1961, p. 91; Lachowicz 1978, p. 31). Archaeological sources from Pomerania did not include objects which could be associated with production of such artefacts, nevertheless, it might be connected with the state of research - most of the discussed "anklets" were discovered outside settlements. The distribution of clay moulds and "semi-products" (specimens with the core inside) indicates that some of that jewellery was also made in the area to west of the Oder River. Due to their comparable chronology, ranging from $\mathrm{HC}$ to $\mathrm{HD}$, it is difficult to conclusively establish the direction of the diffusion of these artefacts. Considering that one of these discoveries comes from Denmark, it can be supposed that a stimulus from the north played a certain role in this process, which has already been suggested in the literature (Lachowicz 1978, p. 22).

The specimens found outside the original territory, e.g. in Słupy, Danków or Kalinówka, are regarded as imports, possibly from Pomerania (e.g. Durczewski [1960] 1961, p. 91; Cofta-Broniewska 1996, p. 49; Dąbrowski 1997, p. 67). Thus the "anklet" from the vicinity of Tykocin should be treated as an object of Pomeranian provenance, both in territorial and cultural terms since most parallels come from this area.

The vicinity of Tykocin, and in a broader sense, the region between the Narew and Biebrza Rivers, was occupied by local groups of the so-called Lusatian culture in the Late Bronze Age. Although it is admitted that they might have processed bronze locally (Dąbrowski 1997, pp. 95, 120, Map 11; Blajer 2001, p. 296; Pawlata [2011-2012] 2012, pp. 29-30,34), arguments in favour of this view are rather weak and poorly documented ${ }^{27}$. There is much more evidence for the functioning of local metallurgy workshops in the area located to the northwest of Tykocin, mostly dated to a later period - HD (Hoffmann 2000, pp. 175-176).

For this reason, it is difficult to regard the Tykocin "anklet" as a locally produced artefact, especially that this type of finds is rather isolated (Kalinówka). It should be accepted that it arrived in the area as a result of exchange. It is impossible to establish whether it was transported to the vicinity of the Narew River directly from Pomerania or via the Kuyavian centre. Mutual relations between these regions, as well as Mazovia, are also indicated by other discoveries, e.g. the hoard found at Brańsk, Bielsk Podlaski district (Jaskanis 1976; Mogielnicka-Urban 2008). Some scholars (Pawlata [2011-2012] 2012, p. 35) assume the existence of a branch of the

${ }^{27}$ One of the discoveries of casting moulds out of the few which have been made (Dąbrowski 1997, Map 11) was rejected with certainty (Młodecka, Urban, Maik 2006-2007). Information concerning the remaining ones usually comes from the Polish Archaeological Record project or from field work reports, thus its interpretation might be of a preliminary nature. 
(Pawlata [2011-2012] 2012, s. 35) zakładają istnienie w omawianym okresie odnogi szlaku handlowego o kierunku północ-południe biegnącej wzdłuż Bugu i wskazują na „...wyraźne ożywienie kontaktów międzykulturowych na obszarze dzisiejszej Polski północnej i północno-wschodniej...”

\section{PODSUMOWANIE}

Znalezisko gromadne z okolic Tykocina nie jest łatwe do interpretacji. Pierwszą wątpliwość budzą już okoliczności jego pozyskania, które nie pozwalają ustalić, czy prezentowane przedmioty faktycznie pochodziły z jednego miejsca. Nie ma pewności także co do tego, czy dysponujemy pełnym zespołem, zwłaszcza że na podstawie innych znalezisk (por. Kazimierz Pomorski, Słupy) można sądzić, iż ozdoby rąk i nóg zazwyczaj deponowano parami. Być może mamy do czynienia ze zniszczonym skarbem. Można przyjąć, iż pierwotnie w jego skład wchodziły „nagolennik” i „bransoleta”. Świadczą o tym nie tylko przesłanki materialne, takie jak zbliżona kolorem patyna. Zwartość zespołu może potwierdzać także pokrywające się datowanie obu typów zabytków oraz to, iż znane są przykłady ich współwystępowania ze sobą w jednym depozycie (Słupy). Trudno natomiast ocenić, czy aplikacje, które nie znajdują bezpośrednich analogii w materiałach $z$ epoki brązu i wczesnej epoki żelaza z obszaru w dorzeczu Odry i Wisły, mogły zostać ukryte wraz z wymienionymi wyżej przedmiotami.

Tzw. nagolenniki puste wewnątrz reprezentujące wariant niezdobiony są zdecydowanie mniej liczne niż te zaliczane do wariantu zdobionego. Występują w znacznym rozproszeniu, choć najwięcej ich pochodzi z Pomorza. Mimo niewielkiej frekwencji można pośród nich wyraźnie wydzielić przynajmniej dwa zbiory: mniejszych i węższych (Kalinówka, Słupy, Kazimierz Pomorski, Danków) oraz większych i proporcjonalnie szerszych (Tykocin, Ciecierzyce, Groß Buchholz), których średnica wewnętrzna nie pozwala na uznanie ich za naszyjniki. Biorąc pod uwagę kolejność odkrycia poszczególnych znalezisk, pierwszy można nazwać grupą Słupy, drugi - grupą Groß Buchholz. Pomiędzy nimi można wyróżnić egzemplarze pośrednie, np. Mieroszyno, Dreitzsch, o średnicach zewnętrznych wielkości tej, jaka występuje w grupie Słupy i średnicy przekroju rzędu tej, jaka charakteryzuje grupę Groß Buchholz. Tej ostatniej pokrewne są okazy o zbliżonej wielkości średnicy zewnętrznej i zdecydowanie mniejszej średnicy przekroju obręczy, co funkcjonalnie zbliża je do naszyjników. Od większości tzw. nagolenników pustych wewnątrz odróżnia je też najprawdopodobniej technika wykonania.

$\mathrm{Na}$ podstawie pojedynczych znalezisk z zachowanymi pozostałościami rdzenia glinianego można stwierdzić, że wykonywano je w technice odlewu, aczkolwiek w odniesieniu do niektórych okazów spotykane są relacje o wykonaniu ich z blachy brązowej (Janowice, Żelazo). Pytanie, czy te egzemplarze należy łączyć z opisywanym typem zabytków, czy jednak traktować jako coś osobnego, uznając sposób wykonania za warunek określający przynależność typologiczną? Informacje rozstrzygające na ten temat mogłyby przynieść badania metaloznawcze 
north-south trade route along the Bug River at that time and suggest "...an obvious increase in intercultural contacts in the area which is the modern territory of northern and north-eastern Poland...."

\section{SUMMARY}

The multiple find from the vicinity of Tykocin is not easy to interpret. Firstly, the circumstances of the discovery raise doubts since it is impossible to establish whether these objects actually came from the same deposit. It is also uncertain if the artefacts represent a complete assemblage, especially that in other assemblages (cf. Kazimierz Pomorski, Słupy) arm and leg jewellery was usually collected in pairs - perhaps this is a damaged hoard deposit. It can be assumed that originally it consisted of the "anklet" and the "bracelet". This is suggested not only by material arguments, such as the patina of similar colours on both. The hypothesis that they came from a sealed context could additionally be supported with the overlapping chronology of the two artefacts as well as attested cases of presence of such items in one deposit (Słupy). However, it is difficult to establish whether the appliqués, which have no direct parallels in Bronze Age and Early Iron Age sources from the basin area of the Oder and Vistula Rivers, might have actually been deposited together with the other items.

The so-called hollow anklets of the undecorated variety are much less common than the decorated ones. They are markedly dispersed, nevertheless, most come from Pomerania. Despite their limited frequency, they can be divided into at least two groups: smaller and narrower ones (Kalinówka, Słupy, Kazimierz Pomorski, Danków) as well as bigger and proportionally wider specimens (Tykocin, Ciecierzyce, Groß Buchholz), whose inner diameter precludes their identification as neck rings. Considering the sequence of discovery of the sites in question, one of them can be called the Słupy group and the other - the Groß Buchholz group. Intermediate specimens can also be distinguished, e.g. from Mieroszyno, Dreitzsch, whose outer diameters are comparable to the ones found in the Słupy group and cross-section diameters are of the order which characterizes the Groß Buchholz group. The latter is associated with artefacts of comparable outer diameters and significantly smaller cross-section diameters, which functionally relates them with neck rings. In addition to that, they are probably distinguished from most of the so-called hollow anklets by the production technique.

On the basis of rather few finds with preserved remains of the clay core it can be established that they were made by casting, however, reports concerning some artefacts claim they were made of sheet bronze (Janowice, Żelazo). This raises a question whether these specimens should be associated with the discussed type of artefacts or rather treated as a separate group, thus recognizing the production technique as a factor defining typological classification. Information which could answer the question might be delivered by metallurgic analysis concerning the structure of alloys, but considering the fact that some of these jewellery pieces have not been 
dotyczące struktury stopu, jednak ze względu na to, iż część z omawianych ozdób nie dotrwała do chwili obecnej, trudno byłoby zweryfikować w ten sposób cały zbiór i wyciągnąć jednoznaczne wnioski. W przypadku „nagolennika” z okolic Tykocina można jedynie stwierdzić, iż zawartość cyny i ołowiu wskazywałaby na wykonanie go z brązu przeznaczonego do obróbki plastycznej, natomiast wysokie udziały antymonu i arsenu mogły utrudniać ten proces. W przypadku ozdób ze Słupów, niski udział pierwiastków „szkodliwych” nie podważa wykonania ich poprzez odlewanie.

Trudno także określić relacje pomiędzy egzemplarzami ornamentowanymi i nieornamentowanymi, szczególnie pod względem wywodzenia się jednych od drugich (por. Kostrzewski 1958, s. 194; Lachowicz 1978, s. 22-23). Bez wątpienia wśród okazów obu wariantów można zaobserwować duże zróżnicowanie formalne, dotyczące m.in. kształtu przekroju. Przy czym, o ile w wariancie zdobionym przekroje rzadko kiedy są koliste (np. Gniewino, Ciecierzyce), to w wariancie niezdobionym - w większości. Może to częściowo wypływać ze stopnia zużycia danego przedmiotu, który w trakcie noszenia przez człowieka zatracał swój pierwotny kształt (następowało spłaszczenie wewnętrznej strony obręczy). Oznaczać by to mogło, że okazy bez ornamentu nie zdążyły jeszcze spełnić swojej funkcji, bądź że była ona inna niż wyrobów zdobionych.

Nie można przy tym zapominać, iż wśród wymienionych wyżej znalezisk $\mathrm{w}$ trzech skarbach (Brzesko, Ciecierzyce, Janowice) okazy gładkie i ornamentowane (typu C według Schacht - zdobione tylko na końcach) współwystępowały ze sobą, a w przypadku Ciecierzyc - były do siebie bliźniaczo podobne. Sugeruje to przynajmniej częściową równoczasowość obu wariantów.

Omawianą grupę zabytków, choć jest niezbyt liczna, trudno zatem uznać za jednorodną. Poza wspominanymi wyżej dyskusyjne są także inne jej wyznaczniki, takie jak forma - o otwartych końcach. Praktycznie wszystkie znaleziska $\mathrm{z}$ terenu Polski spełniają ten warunek, wyjątek stanowią trzy pełne obręcze ze stanowisk niemieckich zaliczane do tego typu ozdób (tabela 4). Zamkniętą formę reprezentuje również pusta w środku ozdoba obręczowa z byłego Trulick na Półwyspie Sambijskim datowana na VI EB (np. Dąbrowski 1968, s. 80-81, 128; por. też przypis 15), przez niektórych badaczy traktowana jako typ odmienny, lokalnego pochodzenia (Hoffmann 2000, s. 139-140). 
preserved to our times, it would be difficult to verify the whole group and draw final conclusions. In the case of the Tykocin "anklet" it can only be stated that the content of tin and lead indicates it was made of bronze used for forming processes while the high content of antimony and arsenic would make such processing more difficult. As far as the artefacts from Słupy are concerned, the low content of "harmful" elements does not contradict casting as the production technique.

It is also difficult to establish the relations between the decorated and undecorated artefacts, particularly in terms of one group giving rise to the other (cf. Kostrzewski 1958, p. 194; Lachowicz 1978, pp. 22-23). Both varieties display significant diversity in terms of forms, connected e.g. with the shapes of cross-sections. While round cross-sections are rare in decorated specimens (e.g. Gniewino, Ciecierzyce), they are found in the majority of the undecorated items. It could partially result from the level of wear of particular objects, which gradually lost their original shapes (the inner side of the ring was flattened). It might mean that the undecorated specimens did not yet perform their function, or that this function was different from the one fulfilled by the decorated artefacts.

At the same time it must be remembered that in three of the mentioned hoards (Brzesko, Ciecierzyce, Janowice) the plain and decorated items (of type C acc. Schacht - decorated only at the ends) were deposited together, and in the case of the Ciecierzyce find, they represented practically identical forms. It suggests at least partial temporal co-existence of both varieties.

The discussed group of artefacts, although not a very big one, cannot be regarded as homogeneous. Apart from the features mentioned above, its other attributes are also disputable, such as the form - penannular one. Practically all the artefacts from Poland meet this condition, with the exception for three solid rings classified into this type of jewellery from German sites (Table 4). The closed form is also represented by a piece of ring jewellery from former Trulick in Sambia, dated to VI EB (e.g. Dąbrowski 1968, pp. 80-81, 128; cf. also note 15), which is treated as a separate type of a local origin by some scholars (Hoffmann 2000, pp. 139-140).

Translated by Barbara Majchrzak (Text) and Iwona Zych (Tables) 


\section{WYKAZ CYTOWANEJ LITERATURY}

\section{BIBLIOGRAPHY OF WORKS CITED}

A n d r zej o w s k a M. 2007, Naszyjniki z Drohiczyna, Sum.: Neckrings from Drohiczyn, „Wiadomości Archeologiczne", 59, pp. 31-43.

B is W. 2015, Badania archeologiczno-architektoniczne, Sum.: Archaeological and architectonic investigations in Tykocin Castle, [in:] Tykocin - zamek nad Narwia (XV-XVIII w.). Badania archeologiczne w latach 1961-1963 i 1999-2007, M. Bis, W. Bis eds., Vetera et nova. Opracowanie źródeł archeologicznych z zasobów IAE PAN nowymi metodami badawczymi, Warszawa.

B l a j e r W. 2001, Skarby przedmiotów metalowych z epoki brązu i wczesnej epoki żelaza na ziemiach polskich, Zusamm.: Horte der Metallgegenstände aus der Bronze- und der frühen Eisenzeit auf der polnischen Gebieten, Kraków.

Bła s z c z y k W. 1965, Cmentarzysko kultury łużyckiej w Częstochowie-Rakowie, Sum.: The cemetery of Lusatian Culture at Częstochowa-Raków, „Rocznik Muzeum w Częstochowie”, 1, pp. 25-224.

Brunn von W.-A. 1968, Mitteldeutsche Hortfunde der jüngeren Bronzezeit, „Römisch-Germanische Forschungen", 29, Berlin.

B u k o w ski Z. 1998, Pomorze w epoce brązu w świetle dalekosiężnych kontaktów wymiennych, Zusamm.: Pommern in der Bronzezeit im Lichte der weitreichenden Tauschkontakte, Gdańsk.

Ch m i ele cki K. 1909, Człowiek przedhistoryczny w Prusiech Zachodnich oraz przewodnik po zbiorach Towarzystwa Naukowego w Toruniu, „Zapiski Towarzystwa Naukowego w Toruniu", I, 7, 8, pp. 135-187.

C h o m e n t o w s k a B. 1960, Brazowy skarb halsztacki z miejscowości Ginetówka, pow. Grójec, Sum.: A bronze Hallstatt hoard from Ginetowka in the Grójec district, „Światowit”, 23, pp. 495-522.

Cofta-Broniewska A. 1996, Metalurgia brązu w świetle źródeł archeologicznych, Zusamm.: Bronzemetallurgie im Lichte archäologischer Funde, [in:] Metalurgia brąu pradziejowych społeczeństw Kujaw, A. Cofta-Broniewska ed., Poznań, pp. 1-127.

Cofta-B ron i ew ska A. 2004, Wytwórczość i użytkowanie brązu, [in:] Archeologiczne badania ratownicze wzdłuz trasy gazociagu tranzytowego, Sum.: Manufacture and use of bronze by the communities of Lusatian Culture, III, Kujawy, 5, Osadnictwo społeczeństw kultur cyklu łużyckiego, J. Bednarczyk, L. Czerniak, A. Kośko eds., Poznań, pp. 441-450.

D ą b r o w s k i J. 1968, Zabytki metalowe epoki brązu między dolna Wisła a Niemnem, Sum.: Metal artefacts from the Bronze Age fund between the lower Vistula and the Niemen, Wrocław-Warszawa-Kraków.

D ą b r o w s ki J. 1997, Epoka brązu w północno-wschodniej Polsce, Zusamm.: Die Bronzezeit im nordöstlichen Polen, Białystok.

Dobrzańska-Szydłowska E., Ged l M. 1962, Cmentarzysko kultury tużyckiej $w$ Łabędach-Przyszówce, pow. Gliwice, Zusamm.: Das Gräberfeld der Lausitzer Kultur in Łabędy-Przyszówka, Kr. Gliwice, „Rocznik Muzeum Górnośląskiego w Bytomiu. Archeologia", 1, pp. 5-115.

D o r k a G. 1939, Urgeschichte des Weizacker-Kreises Pyritz, Stettin.

D u r c z e w s k i D. [1960] 1961, Skarby halsztackie z Wielkopolski, Rés.: Les dépôts hallstattiens en Grande-Pologne, „Przegląd Archeologiczny”, 13, pp. 7-108. 
Erzepki B. 1888, Der Bronzefund von Stupy in Kujavien (Königreich Polen), „Posener Archaeologische Mittheilungen", III, pp. 29-31, Tafel X, XI.

Gr i e s a S. 1982, Die Göritzer Gruppe, Veröffentlichungen des Museums für Ur- und Frühgeschichte Potsdam, 16, Berlin.

H e n s e l Z. 1996, Produkcja wyrobów ze stopów miedzi na Kujawach w świetle badań chemicznych, Sum.: The production of artefacts made of copper alloy from Kujawy in the light of chemical research, [in:] Metalurgia brazu pradziejowych społeczeństw Kujaw, A. Cofta-Broniewska ed., Poznań, pp. 129-193.

Hoffman n M.J. 2000, Kultura i osadnictwo południowo-wschodniej strefy nadbałtyckiej w I tysiącleciu p.n.e., Zusamm.: Kultur und Besiedlung des südöstlichen Ostseegebiets im I. Jahrtausend v. Chr., Olsztyn.

Ja sk a n is D. 1976, Skarb ozdób brązowych kultury łużyckiej z Brańska, gmina loco, woj. białostockie, „Rocznik Białostocki”, 13, pp. 135-149.

Ka s z e w s ki Z. 1973, Skarb z wczesnej epoki żelaza $z$ Łodzi-Teofilowa, Sum.: An early Iron Age hoard from Łódź-Teofilów, „Prace i Materiały Muzeum Archeologicznego i Etnograficznego w Łodzi. Seria Archeologiczna”, 20, pp. 27-38.

Kaźm i e rczak R., Grupa M., Rybka K. 2011, Badania konserwatorskie i metaloznawcze przedmiotów ze stanowiska numer 1 w Wicinie, [in:] Wicina. Katalog zabytków metalowych, Biblioteka Archeologii Środkowego Nadodrza, 5, A. Jaszewska ed., Zielona Góra, pp. 307-313.

K l e e m a n n O. 1976, Steinzeitliche und bronzezeitliche Funde aus der ehemaligen brandenburgischen Neumark, [in:] Certamina praehistorica, 3, O. Kleemann, F.B. Naber, H. Schnitzler eds., Bonner Hefte zur Vorgeschichte, 11, Bonn, pp. 79-129.

Ko s s in n a G. 1915, Die illyrische, die germanische und die keltische Kultur der frühesten Eisenzeit im Verhältnis zu dem Eisenfunde von Wahren bei Leipzig, „Mannus”, 7, pp. 87-126.

Ko strze w ski J. 1923, Wielkopolska $w$ czasach przedhistorycznych, II ${ }^{\text {nd }}$ edition, Poznań.

Ko st r z e w sk i J. [1951-1952] 1953 Wytwórczość metalurgiczna w Polsce od neolitu do wczesnego okresu żelaznego, Rés.: La production métallurgique en Pologne depuis le néolithique jusgu'au premier âge du fer, „Przegląd Archeologiczny”, 9/2-3, pp. 177-213.

Ko st r z e w s k i J. [1953] 1954. Ze studiów nad wczesnym okresem żelaznym w Polsce, Rés.: Etudes sur le premier âge du fer en Pologne, „Slavia Antiqua”, 4, pp. 22-70.

Kostrzewski J. 1958, Kultura łużycka na Pomorzu, Zusamm.: Die Lausitzer Kultur in Pommern, Poznań.

Ko s t r z e w s k i J. [1962] 1964, Skarby i luźne znaleziska metalowe od eneolitu do wczesnego okresu żelaza z górnego i środkowego dorzecza Wisty i górnego dorzecza Warty, Rés.: Les dépôts et les trouvailles isolées en métal depuis lénéolithique jusqu'au premier âge du fer dans le bassin supérieur et moyen de la Vistule et dans le bassin supérieur de la Warta, „Przegląd Archeologiczny", 15, pp. 4-133.

Kr z y s i a k A. 2006, Skarb przedmiotów z brązu z miejscowości Żelazo, gm. Smołdzino, pow. słupski, Sum.: A bronze hoard from Żelazo, Smołdzino commune, Słupsk district, „Pomorania Antiqua", 21, pp. 187-219.

Kubach W. 1985, Einzel- und Mehrstückdeponierungen und ihre Fundplätze, „Archäologisches Korrespondenzblatt", 15/2, pp. 179-186.

Kunkel O. 1931, Pommersche Urgeschichte in Bildern, Stettin.

Kunkel O. 1932, Fundnachrichten des Staatlichen Vertrauensmannes für die kulturgeschichtlichen Bodenaltertümer in Pommern, „Nachrichtenblatt für deutsche Vorzeit”, 8/4, pp. 57-62. 
Lachowicz F. 1978 Wczesnohalsztacki skarb brązowy z Kazimierza Pomorskiego, gmina Będzino, woj. koszalińskie, Zusamm.: Frühhalstatter Bronzeschatz aus Kazimierz Pomorski, Gemeinde Będzino, Wojewodschaft Koszalin, „Materiały Zachodnio-Pomorskie”, 24, pp. 7-33.

Ł u k a L. J. 1966, Kultura wschodniopomorska na Pomorzu Gdańskim, Wrocław-WarszawaKraków.

Młodecka H., Urban J., Maik J., 2006-2007, Ogniwo Leclanchégo $z$ wykopalisk w Surażu, st. 3, pow. Łapy, Sum.: Leclanche cell from the excavations in Suraż, site 3, Łapy district, „Łódzkie Sprawozdania Archeologiczne”, 10, pp. 377-388.

Mogielnicka-U rban M. 2008, Nagolennik typu stanomińskiego z Biejkowskiej Woli k. Biejkowa, gm. Promna, pow. białobrzeski, woj. mazowieckie na tle innych znalezisk tego typu w Polsce, Zusamm.: Beinring von Stanomin-Typ aus Biejkowska Wola bei Biejków, Gm. Promna, Kreis Białobrzeski, Woiw. Mazowieckie angesichts der anderen derartigen Funde in Polen, [in:] Opera ex aere. Studia z epoki brązu i wczesnej epoki żelaza dedykowane profesorowi Janowi Dąbrowskiemu przez przyjaciół, uczniów i kolegów z okazji siedemdziesięciolecia urodzin, M. Mogielnicka-Urban ed., Warszawa, pp. 212-222.

M o g i el n i ck a - U r b a n M. 2014, Analiza zabytków metalowych i kościanych, Sum.: Analysis of metal and bone relics, [in:] Dąbrowski J., Mogielnicka-Urban M. Zespół osadniczy kultury łużyckiej w Maciejowicach, pow. garwoliński, woj. mazowieckie, M. Mogielnicka-Urban ed., Archeologia Mazowsza i Podlasia. Studia i materiały, 5, Warszawa, pp. 107-116.

No s e k E., S tęp iń ski J. 2007, Badanie metaloznawcze wybranych zabytków brązowych ze Szczebrzeszyna. Aneks, Zusamm.: Metallographische Untersuchungen der ausgewählten Bronzefunde von Szczebrzeszyn, [in:] Studia nad epoka brazu i wczesna epoka żelaza w Europie. Księga poświęcona profesorowi Markowi Gedlowi na pięćdziesięciolecie pracy w Uniwersytecie Jagiellońskim, J. Chochorowski ed., Kraków, pp. 391-402.

P a w lat a L. [2011-2012] 2012, Stan i perspektywy badań nas osadnictwem młodszych faz epoki brązu i wczesnej epoki żelaza w północnej części Podlasia, Sum.: The existing studies and prospects of studies over the Late Bronze Age and Early Iron Age settlements in northern part of Podlasie, „Podlaskie Zeszyty Archeologiczne”, 7-8, pp. 5-87.

S c h a c h t S. 1982, Die nordischen Hohlwulste der frühen Eisenzeit, Wissenschaftliche Beiträge der Martin-Luther-Universität Halle-Wittenberg, 68, Halle (Saale).

S i m o n K. 1972, Die Hallstattzeit in Ostthüringen, I, Quellen, Forschungen zur Vor- und Frühgeschichte, 8, Berlin.

Skrzy p e k I. [1995] 1996, Halsztacki skarb brązowy z Malczkowa oraz dwa nieznane nagolenniki z dawnego pow. stupskiego, Zusamm.: Hallstatter Bronzeschatz aus Malczkowo und zwei unbekannte Beinstulpen aus dem ehemaligen Kreis Stolp, „Materiały Zachodnio-Pomorskie", 41, pp. 7-37.

S p r o ck h off E. [1949/50] 1950, Das Lausitzer Tüllenbeil, „Praehistorische Zeitschrift”, 34/35, pp. 76-131.

S p r o ck h off E. 1956, Jungbronzezeitliche Hortfunde der Südzone des nordischen Kreises (Periode V), Kataloge RGZM, 16, Mainz.

S t j e r n qu is t B. [1962-1963] 1963, Präliminarien zu einer Untersuchung von Opferfunden. Begriffsbestimmung und Theoriebildung, „Meddelanden fran Lund Universitets Historiska Museum", pp. 5-64.

S z a f r a ń s k i W. 1955, Skarby brązowe z epoki wspólnoty pierwotnej (IV i V okres epoki brazowej) w Wielkopolsce, Rés.: Les trésors de bronze de l'époque de la communauté primitive (IV-Vépériode de l'âge du bronze) en Grande-Pologne, Warszawa-Wrocław. 
Szczepanek A., Jarosz P., Wi eczorek-Szmal M. 2007, Bogatypochówekpopielnicowy z cmentarzyska w Opatowie, pow. Kłobuck, woj. ślaskie, Zusamm.: Eine reiche Urnenbestattung aus dem Gräberfeld von Opatów, Kr. Kłobuck, Woiw. Śląskie, [in:] Studia nad epoka brązu i wczesna epoka żelaza w Europie. Księga poświęcona profesorowi Markowi Gedlowi na pięćdziesięciolecie pracy w Uniwersytecie Jagiellońskim, J. Chochorowski ed., Kraków, pp. 641-650.

Th $\mathrm{r}$ a n e H. 1980, En boplads fra broncealderns slutning fra Floedemose på Stevns, „Historisk Samfund for Præsto Amt. Årbog 1979-1980”, pp. 21-36.

W ill r o t h K. - H. 1984, Die Opferhorte der älteren Bronzezeit in Südskandinavien, „Frühmittelalterliche Studien. Jahrbuch des Institut für Frühmittelalterforschung der Universität Münster", 18, pp. 48-72. 
